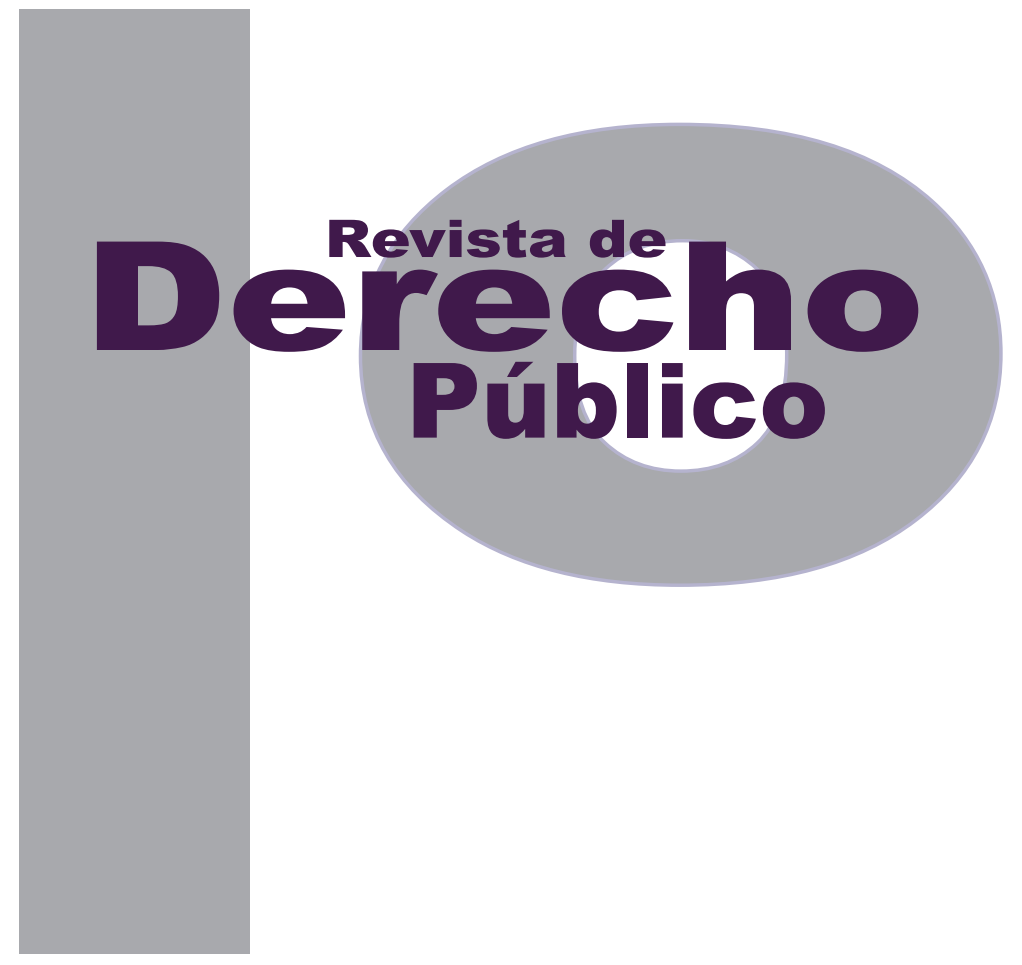

\title{
EFICACIA DEL TRÁMITE INCIDENTAL DE DESACATO COMO MECANISMO PARA LOGRAR EL CUMPLIMIENTO DE LA ORDEN DEL FALLO DE TUTELA
}

\author{
Ángela María Sánchez Rojas
}

Universidad de los Andes

Facultad de Derecho

Revista de Derecho Público N. ${ }^{\circ} 30$

Enero - Junio de 2013. ISSN 1909-7778 


\title{
Eficacia del trámite incidental de desacato como mecanismo para lograr el cumplimiento de la orden del fallo de tutela
}

\author{
Ángela María Sánchez Rojas*
}

RESUMEN

La acción de tutela se ha convertido en un mecanismo de protección de gran importancia en el ordenamiento jurídico colombiano, pues resulta ser el medio por el cual las personas encuentran la protección efectiva de sus derechos fundamentales. No obstante, en la práctica se ha observado que después de que el juez constitucional procede a dar la orden de amparo de estos derechos, no hay un efectivo y acucioso cumplimiento de esta. Así las cosas, el actor debe acudir ante el juez para que active los mecanismos de cumplimiento del recurso de amparo y, si es necesario, tome las medidas sancionatorias respectivas. Después de hacer un análisis de varios casos concretos en Bogotá, Colombia, se observa que las medidas que toma el juez constitucional resultan ser imprecisas o incluso vagas para que haya efectivo acatamiento a la orden, convirtiéndose el fallo de tutela en un simple "canto a la bandera".

Palabras clave: acción de tutela, derechos fundamentales, incidente de desacato, mecanismos de cumplimiento, eficacia del derecho, orden.

\begin{abstract}
The writ of amparo has become a protective mechanism of great importance in the Colombian legal system; it is the means by which people find effective protection of their fundamental rights. However, in practice it has been observed that after the constitutional judge proceeds to give the order for the defense of these rights, there is a inefficient implementation of it. So, the plaintiff has to come up to the judge to trigger enforcement mechanisms, and if necessary, take the respective sanctioning measures. After an analysis of several specific cases in Bogotá, Colombia, it appears that the measures taken by the constitutional judge found to be inaccurate or vague to have effective compliance order, becoming the statement in a simple "singing the flag".
\end{abstract}

KEY WORDS: writ of rights, fundamental rights, contempt incident, compliance mechanisms, eficacy of law, order.

\footnotetext{
Abogada de la Universidad de los Andes. Cargo actual: auxiliar judicial, Corte Constitucional. Correo: angelasr@corteconstitucional.gov.co
} 


\section{SUMARIO}

Introducción - I. LA ACCIÓN DE TUTELA COMO MECANISMO PREFERENTE DE PROTECCIÓN DE DERECHOS CONSTITUCIONALES FUNDAMENTALES - A. ¿Cómo surgió la acción de tutela en el ordenamiento jurídico colombiano? - B. La tutela no puede ser usada como mecanismo principal, salvo que no se disponga de otro medio judicial o se busque evitar la ocurrencia de un perjuicio irremediable - C. El derecho a reclamar la protección inmediata y sus consecuencias en la procedencia de la acción de tutela - D. El trámite y orden de tutela como forma de proteger el derecho constitucional fundamental - II. LOS MECANISMOS DE CUMPLIMIENTO PARA HACER EFECTIVA LA ORDEN DEL FALLO DE TUTELA - A. El cumplimiento del fallo de tutela según lo dispuesto en el artículo 27 del Decreto 2591 de 1991 - B. El trámite incidental de desacato como mecanismo de cumplimiento de la acción de tutela - 1. Trámite del incidente de desacato - 2. La responsabilidad subjetiva como medio para determinar si se debe iniciar trámite incidental de desacato - 3. Inconformidad con la decisión del trámite incidental de desacato y sus recursos - 4. Los incidentes de desacato no deben ser enviados a la Corte Constitucional para su eventual revisión - 5. ¿Cómo están fallando los jueces constitucionales al encontrarse frente al trámite incidental de desacato? Casos concretos - III. PROBLEMÁTICA EN EL TRÁMITE INCIDENTAL DE DESACATO PARA HACER EFECTIVA LA ACCIÓN DE TUTELA - A. Problemática en la falta de regulación concreta del trámite incidental de desacato - $B$. $L a$ falta de recursos para alegar la decisión del incidente de desacato - $C$. El incidente de desacato no llega a revisión a la Corte Constitucional - IV CONCLUSIONES - Bibliografía. 
Introducción

Resulta triste encontrar que en Colombia, aun cuando la Carta Política de 1991 y las leyes exigen la protección de los derechos constitucionales fundamentales en todo momento, siguen aumentando las situaciones en las que las personas deben acudir a la acción de tutela para encontrar el amparo de dichos derechos. En efecto, se siguen evidenciando casos en los que una persona de la tercera edad solicita su pensión de vejez y la entidad encargada de otorgarle la prestación no responde; en que un desplazado solicita prórroga de la ayuda humanitaria porque no tiene recursos para asegurar su existencia y la entidad responsable de entregarla le da un turno desproporcional con la naturaleza del subsidio; en que un ciudadano por su estado de salud requiere un servicio médico pero el ente correspondiente no le brinda la atención requerida; y lo más preocupante de todo, se ha observado situaciones en que la persona debe acudir a este recurso de amparo porque encuentra que los mecanismos ordinarios son tan lentos y dispendiosos que, de esperar, podría concurrir un perjuicio irremediable.

Conforme a lo expuesto, puede verse entonces que la acción de tutela se ha convertido en un mecanismo de protección de gran importancia en el ordenamiento jurídico colombiano, pues en él las personas encuentran la protección efectiva de los derechos fundamentales dentro de un término breve. Para tales efectos, cuando el juez comprueba que un derecho constitucional fundamental ha sido vulnerado, la orden que este profiere, en teoría, debería ser cum- plida rápida y cabalmente. Sin embargo, en la práctica jurídica $^{2}$ se ha visto que después de que el juez procede a dar la orden de amparo de los derechos fundamentales, empiezan a surgir inconvenientes para el efectivo cumplimiento de lo dispuesto en el fallo, a pesar de que normalmente, dentro de la orden, se otorga un plazo perentorio de cuarenta y ocho (48) horas a partir de la notificación de la providencia, para que la parte accionada proceda a acatarla.

Así pues, al seguir presentándose la vulneración de los derechos protegidos, la parte afectada debe acudir ante el juez constitucional para que active los mecanismos de cumplimiento de la orden de amparo, constriña la parte accionada $y$, de encontrar responsabilidad subjetiva en su incumplimiento, la sancione mediante incidente de desacato. Podría pensarse entonces que el demandante cuenta con un recurso sancionatorio eficaz para que se cumpla la orden dada por el juez, sin embargo distintas situaciones evidencian que al enfrentarse el juez constitucional a este trámite incidental, procede a tomar medidas que resultan ser imprecisas o incluso vagas para su efectivo cumplimiento.

En algunas ocasiones, a pesar de evidenciarse el desinterés de la parte accionada para cumplir con la orden del fallo de tutela, el juez procede a enviarle requerimientos sin abrir el respectivo incidente de desacato. Ha habido situaciones

2 . El presente problema lo empecé a detectar cuando interpuse por primera vez acciones de tutela de usuarios del Consultorio Jurídico de la Universidad de los Andes. Aunque había orden de amparo, la entidad accionada no acataba la orden del fallo de tutela, a pesar del plazo perentorio de cuarenta y ocho (48) horas para su cumplimiento. Por lo anterior, la parte accionante debía iniciar trámite incidental de desacato, sin que este tampoco surtiera ningún efecto positivo para el cumplimiento de la orden de tutela. 
en las que pasan semanas, incluso meses, sin que el accionado tome las medidas necesarias para hacer efectiva la orden de amparo, a pesar de los requerimientos. En otras oportunidades, no obstante que el juez mediante trámite incidental determina la responsabilidad subjetiva del accionado frente al incumplimiento del fallo, profiere sanciones insignificantes que solo acrecientan el grado de vulneración. Incluso, se ha observado que la parte afectada debe elevar varios incidentes de desacato, porque la entidad sancionada cumple la orden solo por un tiempo.

¿Qué está pasando entonces con los mecanismos de cumplimiento de la acción de tutela?, ¿están siendo correctamente empleados por los jueces de tutela?, ¿existe una regulación estricta frente al trámite incidental de desacato?, ¿qué pasa entonces, cuando se encuentra responsabilidad subjetiva de la parte accionada en el incumplimiento de la orden del fallo de tutela?, ¿cuál es la naturaleza jurídica del incidente de desacato para que se cumpla efectivamente lo dispuesto en el fallo de tutela?, ¿no llega el incidente de desacato a la Corte Constitucional para su eventual revisión de la misma forma que la acción de tutela?, ¿teniendo en cuenta que la acción de tutela es un mecanismo preferente y sumario para la protección urgente de los derechos fundamentales de las personas, sus mecanismos de cumplimiento no deberían tener la misma naturaleza?, ¿cuál está siendo el actuar de los jueces para que haya cumplimiento de la orden de amparo de los derechos fundamentales?, ¿hay entonces efectividad en el trámite incidental de desacato como mecanismo para cumplir la orden del fallo de tutela?
Con base en lo expuesto, y con el fin de responder las anteriores inquietudes, el presente proyecto de investigación busca estudiar la eficacia del trámite incidental de desacato, como mecanismo para lograr el cumplimiento de la orden proferida en el fallo de tutela dentro del ordenamiento jurídico colombiano, a través de: a) un análisis teórico en el que se hará un recuento de la institución jurídica de la acción de tutela desde su origen en la Asamblea Nacional Constituyente de 1991, su naturaleza, requisitos esenciales, trámite preferente y alcance de la orden del fallo de tutela, así como los mecanismos existentes en el ordenamiento jurídico colombiano para lograr el cumplimiento de la orden proferida en el fallo de tutela. Atendiendo el problema jurídico a resolver, el enfoque mayor estará en el trámite incidental de desacato como mecanismo sancionatorio, cuyo único objetivo es lograr el cumplimiento efectivo de lo dispuesto en la orden del fallo de tutela; b) un análisis práctico a partir de la exposición de quince casos concretos en los que se ejemplifica el proceder del juez constitucional al enfrentarse a un incidente de desacato, y su respectiva coherencia con el fin esencial de la acción de tutela: la protección inmediata y urgente de los derechos fundamentales de las personas; c) un análisis crítico donde se expondrá, de manera concreta, las principales falencias del trámite incidental de desacato que afectan su efectividad y aplicabilidad según la naturaleza jurídica de su institución.

Finalmente, como breve conclusión, se explicará el concepto de eficacia según la teoría de Germán Castro Villegas, y en virtud de este se procederá a hacer un análisis somero de la efec- 
tividad del trámite incidental de desacato para lograr el cumplimiento de la orden del fallo de tutela.

\section{LA ACCIÓN DE TUTELA COMO MECANISMO PREFERENTE DE PROTECCIÓN DE DERECHOS CONSTITUCIONALES FUNDAMENTALES ${ }^{3}$}

\section{A. ¿Cómo surgió la acción de tutela en el ordenamiento jurídico colombiano?}

Después de varios años de múltiples intentos faIlidos de reforma constitucional por la vía parlamentaria, seguidos por una crisis de gobernabilidad, legitimidad y eficacia de las instituciones jurídicas dispuestas en la Constitución Política de 1886, el 5 de febrero de 1991 el Presidente de la época, César Gaviria Trujillo, daba su discurso de instalación de la Asamblea Nacional Constituyente de 1991 expresando:

Todo colombiano ha sufrido en carne propia, o visto sufrir a un compatriota, porque nadie escucha su reclamo o su pequeña queja. Todos hemos presenciado la indignación de un amigo porque no se hizo justicia a la hora de definir una controversia. Y lo que es aún más grave, todos sabemos que esta agresividad característica de los colombianos, se nutre del irrespeto por la vida, la intolerancia, de atropellos

3 . Se habla de derechos constitucionales fundamentales refiriéndose a los dispuestos en la Constitución Política. En este sentido, el artículo 2 del Decreto 2591 de 1991 establece: "La acción de tutela garantiza los derechos constitucionales fundamentales. Cuando una decisión de tutela se refiera a un derecho no señalado expresamente por la Constitución como fundamental, pero cuya naturaleza permita su tutela para casos concretos, la Corte Constitucional le dará prelación en la revisión de esta decisión". cotidianos, de frecuentes actitudes arrogantes. Los colombianos se han rebelado pacíficamente contra esta situación. Cansados de los privilegios quieren recibir un trato justo. Ante tanto abuso y utilitarismo piden ser respetados en su dignidad. Frente a la discriminación, exigen igualdad de atención de las autoridades. Al sentirse desamparados reclaman garantía eficaz para sus derechos. ${ }^{4}$

Aun cuando por vía de recepción internacional existía formalmente un recurso judicial efectivo antes de $1991^{5}$, el ordenamiento jurídico colombiano se encontraba "cojo" respecto a la existencia de un mecanismo sencillo y eficaz para la protección de los derechos fundamentales de los ciudadanos, que les permitiera acudir a alguna instancia judicial para reclamar dicha protección. A su vez, la Constitución de 1886 partía de la premisa de que la validez de los derechos constitucionales estaba condicionada a su reconocimiento en las leyes (Barreto, 1996, p. 38).

Con fundamento en lo anterior, la Asamblea Nacional Constituyente, motivada en un cambio estructural de las instituciones existentes en el ordenamiento jurídico colombiano, en procura de una transformación del Estado en un Estado social de derecho fundado en el respeto de la dignidad humana, en el trabajo y la solidaridad

Palabras del presidente de la República, César Gaviria Trujillo, en el Discurso de instalación de la Asamblea Nacional Constituyente. Febrero 5 de 1991. En: Presidencia de la República. Los derechos fundamentales, protección de todos: libro blanco de la tutela. Bogotá: Imprenta Nacional de Colombia. Mediante la Ley 16 de 1972, Colombia ratificó la Convención Americana de Derechos Humanos, que en su artículo 25, numeral 1 establece: "toda persona tiene derecho a un recurso sencillo y rápido o a cualquier otro recurso efectivo ante los jueces o tribunales competentes, que la ampare contra actos que violen sus derechos fundamentales..." 
de las personas que lo integran ${ }^{6}$, instituyó no solamente nuevas disposiciones de derechos, sino también instituciones jurídicas que tenían como fin primordial la protección efectiva de los derechos fundamentales de todas las personas, extender la participación ciudadana y lograr mejores niveles de convivencia, desarrollo y justicia social (Vidal \& Sáchica, 1991, p. 23).

Desde sus inicios, la Asamblea Nacional Constituyente basó sus discusiones en la idea que poco se avanzaría con la mera enunciación de una amplia serie de derechos fundamentales en la nueva Constitución Política, si no se creaban garantías eficaces para su protección y promoción. En ese sentido, se expresó: “más allá de la sola declaración de los derechos, importa el establecimiento de una serie de instrumentos que realmente permitan a cualquier persona obtener el goce efectivo de los mismos." (Asamblea Nacional Constituyente, 1991, p. 7 y ss.). Así las cosas, y ante el surgimiento de nuevas realidades sociales, se proyectó la creación de nuevas instituciones jurídicas para proteger los derechos de todos los ciudadanos, como la acción de cumplimiento, la acción popular y la acción de tutela.

Después de hacer un análisis de distintos instrumentos jurídicos existentes en otros ordenamientos (Asamblea Nacional Constituyente, 1991, p. 4), la Asamblea Nacional Constituyente determinó que la protección de los derechos constitucionales fundamentales debía desligarse de otro tipo de derechos particulares, como el habeas corpus o la excepción de constitu-

6 . Constitución Política de 1991, artículo 1. cionalidad (Esguerra, 1991). En consecuencia, dispuso en el Título II, Capítulo 4, artículo 867 de la Carta Política, un mecanismo preferente ${ }^{8}$ de carácter subsidiario y autónomo ${ }^{9}$, enfocado a la protección de los derechos constitucionales fundamentales Ilamado "acción de tutela". Con esta acción, todas las personas podrían exigir, sin ningún tipo de discriminación o dilación, la garantía de sus derechos fundamentales constitucionales, ante la amenaza o violación de estos por parte de cualquier autoridad pública o de particulares, en determinadas circunstancias ${ }^{10}$.

Esta acción es entonces un mecanismo informal ${ }^{11}$ y rápido para acudir a la administración

7 . ARTíCULO $86^{\circ}$.- Toda persona tendrá acción de tutela para reclamar ante los jueces, en todo momento y lugar, mediante un procedimiento preferente y sumario, por sí misma o por quien actúe a su nombre, la protección inmediata de sus derechos constitucionales fundamentales, cuando quiera que éstos resulten vulnerados o amenazados por la acción o la omisión de cualquier autoridad pública. La protección consistirá en una orden para que aquél respecto de quien se solicita la tutela, actúe o se abstenga de hacerlo. El fallo, que será de inmediato cumplimiento, podrá impugnarse ante el juez competente y, en todo caso, éste lo remitirá a la Corte Constitucional para su eventual revisión. Esta acción sólo procederá cuando el afectado no disponga de otro medio de defensa judicial, salvo que aquélla se utilice como mecanismo transitorio para evitar un perjuicio irremediable. En ningún caso podrán transcurrir más de diez días entre la solicitud de tutela y su resolución. La ley establecerá los casos en los que la acción de tutela procede contra particulares encargados de la prestación de un servicio público o cuya conducta afecte grave y directamente el interés colectivo, o respecto de quienes el solicitante se halle en estado de subordinación o indefensión.

8 . Debe ser tramitada por un juez, antes de entrar a analizar cualquier otro caso, con excepción al habeas corpus.

9 . En sentencia T-335 de 1997 la Corte Constitucional aclaró que la acción de tutela tiene un carácter autónomo pues "por la inmediatez, que le es inherente, puede impetrarse del Estado con base en una sola e informal interposición, sin que dependa de otro procedimiento judicial ni tenga que intentarse en conjunto con el ejercicio de acciones judiciales diferentes, ordinarias, o especiales".

10 . Debe ser tramitada por un juez, antes de entrar a analizar cualquier otro caso, con excepción al habeas corpus. Artículo 16 del Decreto 2591 de 1991.

11 . Corte Constitucional. Sentencia T-264 de 2003. Con el fin de hacer de la acción de tutela un mecanismo eficaz, se estructuró la acción de tutela con muy pocos formalismos y tecnicismos. Así, se determinó que 
de justicia (Art. 229 Const. Pol.), en busca de la protección de los derechos fundamentales ante las posibles fallas de una autoridad pública o abusos de particulares. En su primera sentencia, T-001 de $1992^{12}$, la Corte Constitucional precisó que:

Se trata, entonces, de un instrumento jurídico confiado por la Constitución a los jueces, cuya justificación y propósito consisten en brindar a la persona la posibilidad de acudir sin mayores requerimientos de índole formal y en la certeza de que obtendrá oportuna resolución, a la protección directa e inmediata del Estado, a objeto de que, en su caso, consideradas sus circunstancias específicas y a falta de otros medios, se haga justicia frente a situaciones de hecho que representen quebranto o amenaza de sus derechos fundamentales, logrando así que se cumpla uno de los fines esenciales del Estado, consistente en garantizar la efectividad de los principios, derechos y deberes consagrados en la Constitución (art. 2o. Const. Pol.).

Ahora bien, aunque esta acción operaba en el marco constitucional, requería para mayor agilidad, aplicabilidad, eficacia y garantía de una regulación que estableciera unos criterios de procedibilidad, alcance y sanciones. Por esta razón, el artículo $5^{\circ}$ transitorio de la Constitución Política de Colombia de 1991, revistió al Presidente de la República de precisas facultades extraordinarias para reglamentar la acción

esta no solo puede ser presentada de manera oral o escrita, sino que con solo escribir los hechos podrá ser suficiente para que el juez dé la orden de protección (artículo 14, Decreto 2591 de 1991). Esto quiere decir, entonces, que la persona puede no escribir sus pretensiones o fundamentos de derecho, el juez debe, de oficio, corregir las pretensiones y dar la orden de protección, en concordancia con el principio iura novit curia: al juez se le dan los hechos y el da el derecho.

M. P.: José Gregorio Hernández Galindo, 3 de abril de 1992. de tutela, resultando así el Decreto Ley 2591 de 1991 "Por el cual se reglamenta la acción de tutela consagrada en el artículo 86 de la Constitución Política" ${ }^{13}$.

De esta manera, el Decreto Ley 2591 de 1991 dispuso los elementos esenciales que debían tenerse en cuenta al momento de interponer la acción de tutela, los requisitos mínimos de procedibilidad, la legitimación para actuar dentro del trámite ${ }^{14} y$ las sanciones a las que habría lugar en caso de incumplimiento de lo dispuesto en la orden del fallo de tutela.

En lo que refiere a los elementos esenciales de la acción de tutela, ha de recordarse lo dispuesto en la sentencia T-001 de 1992:

Tiene, pues, esta institución, como dos de sus caracteres distintivos esenciales (..) los de la subsidiariedad y la inmediatez; el primero por cuanto tan solo resulta procedente instaurar la acción cuando el afectado no disponga de otro medio de defensa judicial, a no ser que busque evitar un perjuicio irremediable (art. 86, inc. 3, Constitución Política); el segundo, puesto que no se trata de un proceso sino de un remedio de aplicación urgente que se hace preciso administrar en guarda de la efectividad concreta y actual del derecho sujeto a violación o amenaza.

13 . Posteriormente, el 19 de febrero de 1992, el Presidente de la República, en virtud de las facultades atribuidas por el artículo 189, numeral 11 de la Constitución Política, emitió el Decreto 2591 de 1991.

14 . El artículo 10 del Decreto Ley 2591 de 1991 dispone que la acción de tutela podrá ser interpuesta por cualquier persona vulnerada o amenazada en uno de sus derechos fundamentales, quien podrá actuar por sí misma o a través de apoderado. Igualmente podrá ser agenciada cuando alguien no pueda interponerla por sus mismas condiciones, o la podrá interponer el Defensor del Pueblo y los personeros municipales. 


\section{B. La tutela no puede ser usada como mecanismo principal, salvo que no se disponga de otro medio judicial o se busque evitar la ocurrencia de un perjuicio irremediable}

Aunque el constituyente de 1991 había dispuesto dentro de la norma constitucional el carácter subsidiario de la acción de tutela, el Decreto Ley 2591 de 1991 reiteró en su artículo $6^{\circ}$ que una de las causales de improcedencia de este mecanismo de amparo es la existencia de un medio ordinario para resolver la situación alegada, situación en la cual se debe acudir a este antes que al recurso de amparo, salvo que la acción de tutela sea utilizada como mecanismo transitorio para evitar un perjuicio irremediable, mientras hay alguna decisión dentro del proceso ordinario. En otras palabras, no se instituyó la acción de tutela para que se acuda a ella simplemente por ser más ágil o rápida, pues su finalidad no es ser un recurso alternativo a los otros medios jurisdiccionales existentes, de modo que pueda utilizarse uno u otro sin ninguna distinción, ${ }^{15}$ tampoco fue estructurada para desplazar a los jueces ordinarios del ejercicio de sus atribuciones propias. ${ }^{16}$

Por consiguiente, si existen otras instancias judiciales que resultaren eficaces para la protección que se reclama, el interesado debe acudir a ellas antes de pretender el amparo por vía de tutela ${ }^{17}$, pues esta acción se incorporó a la Carta "con el fin de llenar los vacíos que pudie-

15 . Corte Constitucional. Sentencia T-327 de 1994.

16 . Corte Constitucional. Sentencia T-1048 de 2010.

17 . Corte Constitucional. Sentencia T-441 de 2003. ra ofrecer el sistema jurídico para otorgar a las personas una plena protección de sus derechos esenciales" ${ }^{18}$.

\section{El derecho a reclamar la protección inmediata y sus consecuencias en la procedencia de la acción de tutela}

Ahora bien, teniendo en cuenta que el fin primordial de la acción de tutela es la protección efectiva e inmediata ${ }^{19}$ de los derechos fundamentales de las personas, para evitar la ocurrencia de un perjuicio irremediable ${ }^{20}$ la jurisprudencia constitucional ha desarrollado también otro requisito de procedibilidad de este mecanismo de amparo. En esa medida, se ha establecido que esta acción debe presentarse dentro de un plazo razonable desde el inicio de la amenaza o vulneración ${ }^{21}$. Lo anterior, considerando que si esta pudiera interponerse en cualquier momento, por ejemplo, años después de ocurrido el agravio a los derechos fundamentales, dejaría de tener sentido su existencia, pues no habría la "protección inmediata" característica de esta acción ${ }^{22}$. Por otro lado, se ha dicho que

18

Corte Constitucional. Sentencia T-390 de 2012

19 . A causa de diferentes interpretaciones respecto al principio de inmediatez por parte de los jueces constitucionales, la Corte Constitucional en sentencia SU-961 de 1999 determinó que, a pesar de que la acción de tutela puede ser presentada "en todo momento" y no tiene ningún término de prescripción y caducidad, ha de tenerse en cuenta un requisito fundamental para la procedencia de la misma: el principio de inmediatez.

20 . Corte Constitucional. Sentencia T- 078 de 2009; DueñAs, R. (2003, p. 5).

21 . Corte Constitucional. Sentencia T-1028 de 2010; también T-290 de 2011, T-607 de 2008 y T-123 de 2007.

22 . Corte Constitucional. Sentencia SU-961 de 1999, T-461 de 2001, T-105 de 2002, T-173 de 2002 y T-315 de 2005. 
se "justifica la exigencia de dicho término toda vez que con este se impide el uso de este mecanismo excepcional como medio para simular la propia negligencia o como elemento que atente contra los derechos e intereses de terceros interesados" 23 .

Aunque pareciera restrictivo este principio, la Corte Constitucional ha estipulado algunas excepciones bajo las cuales se justificaría el amplio lapso que hubiese transcurrido entre la vulneración de los derechos fundamentales y la solicitud del amparo, siendo estas:

(i) La existencia de razones válidas para la inactividad, como podría ser, por ejemplo, la ocurrencia de un suceso de fuerza mayor o caso fortuito, la incapacidad o imposibilidad del actor para interponer la tutela en un término razonable, la ocurrencia de un hecho completamente nuevo y sorpresivo que hubiere cambiado drásticamente las circunstancias previas, entre otras.

(ii) Cuando a pesar del paso del tiempo es evidente que la vulneración o amenaza de los derechos fundamentales del accionante permanece, es decir, su situación desfavorable como consecuencia de la afectación de sus derechos continúa y es actual.

(iii) Cuando la carga de la interposición de la acción de tutela en un plazo razonable resulta desproporcionada, dada la situación de debilidad manifiesta en la que se encuentra el accionante, lo que constituye un trato preferente autorizado por el artículo 13 de la Constitución

23

Corte Constitucional. Sentencia T-290 de 2011
Política, que ordena que "el Estado protegerá especialmente a aquellas personas que por su condición económica, física o mental, se encuentren en circunstancia de debilidad manifiesta y sancionará los abusos o maltratos que contra ellas se cometan" 24 .

\section{Trámite y orden de tutela como forma de proteger el derecho constitucional fundamental}

Habiendo expuesto la naturaleza, el concepto y requisitos más destacados de procedibilidad de la acción de tutela, resulta necesario entrar a estudiar tres aspectos: el trámite preferente de la acción de tutela, el contenido del fallo de tutela y la orden de tutela. Esto proporcionará el marco jurídico para determinar por qué surgen los mecanismos de cumplimiento de la acción de tutela, específicamente el trámite incidental de desacato, objeto de estudio de esta investigación.

En primera instancia ha de mencionarse que al ser la acción de tutela un medio preferente e inmediato, el legislador dispuso que cualquier juez de la República puede conocer de esta ${ }^{25}$, por consiguiente, la persona quien considere que se le ha amenazado o vulnerado un derecho fundamental podrá acudir ante cualquier juez del lugar donde ocurriere la amenaza ${ }^{26}$. Tratándose

24 . Corte Constitucional. Sentencia T-1110 de 2002; véanse también T-158 de 2006 y T-485 de 2011.

Es importante aclarar que, aunque cualquier juez puede conocer de la acción de tutela, el Decreto 1382 de 2000 con el fin de racionalizar y desconcentrar su conocimiento estableció las reglas de reparto y competencia de esta.

Artículo 37, Decreto 2591 de 1991. 
particularmente del término para conceder o no la tutela, "de acuerdo con la naturaleza de la acción establecida por el artículo 86 de la Carta, toda demanda de tutela instaurada ante los jueces de la República debe ser tramitada y fallada dentro del término constitucional" 27 , en este sentido, esta debe fallarse en primera instancia en un término de diez (10) días ${ }^{28}$ y en segunda instancia en un término de veinte (20) días ${ }^{29}$.

Ahora bien, respecto al contenido del fallo de tutela, la Corte Constitucional en sentencia T-086 de 2006 distinguió dos partes constitutivas:

La misión primordial que la Constitución encomienda al juez de tutela es decidir si en cada caso concreto el derecho invocado por el accionante ha sido violado o amenazado y, en caso de que así sea, es su deber tutelarlo y, en consecuencia, tomar las medidas necesarias para que cese la violación o la amenaza. Entonces, se pueden distinguir dos partes constitutivas del fallo: la decisión de amparo, es decir, la determinación de si se concede o no el amparo solicitado mediante la acción de tutela, y la orden específica y necesaria para garantizar el goce efectivo del derecho amparado.

En virtud de lo anterior, y en concordancia con lo dispuesto en el artículo 29 del Decreto Ley 2591 de 1991, el fallo deberá contener: a) la identificación del accionante; b) la identificación de la parte accionada; c) la determinación del derecho tutela; d) el término perentorio para que se cumpla la orden de amparo y e) la orden

27 . Corte Constitucional. Sentencia T-034 de 1994.

Artículo 29, Decreto 2591 de 1991 y definición precisa de la conducta a cumplir con el fin de hacer efectiva la tutela. Esta última es la que da el alcance del contenido material de la decisión ${ }^{30}$, garantiza el pleno goce del derecho $y$, si fuera posible, se repare el daño.

Para el efecto, el juez constitucional al proferir la orden no puede pronunciarse en forma general o abstracta, pues su función debe ser ordenar, para el caso, las medidas necesarias para garantizar al agraviado el pleno goce de su derecho y, si es pertinente, volver las cosas al estado en que se encontraban antes de la violación (Barreto, 1996, p. 94). Por esta razón,

las órdenes que se impartan en materia de tutela han de ser claras, específicas y contundentes, relativas a la situación que se estima configurada en la vulneración de los derechos y referentes de manera precisa e indudable a la manera como el juez concibe que ellos quedarán eficiente y prontamente amparados (Correa, 2009, p. 197).

Ahora bien, ha de precisarse que el juez constitucional puede fallar extra y ultra petita, pues está dentro de sus funciones asegurar que se proteja de manera integral y efectiva los derechos constitucionales fundamentales que están siendo amenazados o vulnerados (Correa, 2009, p. 197). Por esta razón, si este considera que para proteger los derechos fundamentales se debe ordenar algo que no esté dentro de las pretensiones solicitadas por la parte accionante, puede proferir la orden adecuada para que se protejan los derechos constitucionales alegados.

30 . Corte Constitucional. Sentencia T-086 de 2003 
Respecto al alcance de la orden de tutela, en concordancia con lo dispuesto en el artículo 86 de la Carta Política ${ }^{31}$ el artículo 23 del Decreto 2591 de 1991 dispuso que cuando la solicitud en la acción de tutela se dirija contra una acción de la autoridad, el fallo tendrá por objeto garantizar al accionante el pleno goce de su derecho y volver al estado anterior a la violación. Así pues, la orden del juez constitucional puede ser de hacer o de no hacer y, excepcionalmente, de dar, por ejemplo, pagar dinero ${ }^{32}$. Lo anterior se define dependiendo de si el caso es de violación por acción o por omisión. “En el primer evento, o sea la violación por acción, la orden del juez de tutela se endereza a procurar "su inmediata cesación" (orden de no hacer); en el segundo evento, o sea violación por omisión, la orden se dirige a procurar la realización de "la acción adecuada (orden de hacer)" (Correa, 2009, p. 193).

La Corte Constitucional ha expresado que "el derecho a la tutela judicial efectiva y el debido proceso, así como el principio de seguridad jurídica obligan a la persona a quien está dirigida la orden de tutela, a cumplirla de manera pronta y oportuna en los términos en los cuales ha sido establecido por la sentencia que ha hecho tránsito a cosa juzgada". Por lo tanto, la orden deberá cumplirse en un plazo perentorio de cuarenta y ocho (48) horas siguientes a la notifica-

31 . Artículo 86 , incisos $2^{\circ}$ y $3^{\circ}$ : "Consistirá en una orden para que aquél respecto de quien se solicita la tutela, actúe, o se abstenga de hacerlo. El fallo, que será de inmediato cumplimiento, podrá impugnarse".

32 . Es importante tener en cuenta que el juez de tutela puede fallar sobre algo no pedido (extra petita) o conceder más de lo que se aspiraba (ultra petita) con el fin de hacer eficaz e inmediata la protección de los derechos fundamentales alegados. Corte Constitucional. Sentencia T-063 de 2000. ción del fallo, sin embargo ha de recordarse que la Corte Constitucional ha determinado que en algunas excepciones este plazo se podrá extender cuando sea de imposible cumplimiento ${ }^{33}$, o podrá ser menor dependiendo de la gravedad del asunto ${ }^{34}$.

\section{LOS MECANISMOS DE CUMPLIMIENTO PARA HACER EFECTIVA LA ORDEN DEL FALLO DE TUTELA}

Los instrumentos y sanciones dirigidas a garantizar el cumplimiento de las órdenes proferidas por el juez constitucional deberían ser, al igual que la acción de tutela, un mecanismo preferente y de inmediato acatamiento para asegurar la guarda de la orden judicial de protección de los derechos invocados. Sin embargo, como se mencionó anteriormente, existen unos problemas estructurales en el trámite de acción de tutela referentes a sus mecanismos de cumplimiento, los cuales ni la jurisprudencia constitucional y ni el Decreto 2591 de 1991, que dispone las facultades sancionatorias del juez constitucional para que haya cumplimiento de la orden de tutela, han podido sanear.

Con el fin de hacer un análisis al respecto, este capítulo comenzará explicando los mecanismos de cumplimiento con los que cuenta el juez constitucional para que haya obediencia a lo

\footnotetext{
33 . Corte Constitucional. Sentencia T-116 de 1993 y T-014 de 1994.

34 . En la sentencia T-211 de 1995 se dio un plazo de doce horas para que se cumpliera la orden de reintegrar al colegio a una alumna embarazada.
} 
dispuesto en sentencia de tutela, siendo estos el cumplimiento del fallo según lo ordenado en el artículo 27 del Decreto 2591 de 1991 y el incidente de desacato regulado en el artículo 52 del mismo Decreto. Para poder entender sus diferencias principales se estudiará la naturaleza, trámite procesal y desarrollo jurisprudencial de cada uno de estos mecanismos. Consecuente con lo anterior, se hará una exposición de casos concretos para contrastarlos con la regulación referente al incidente de desacato y analizar su verdadera eficacia. Para tal efecto, se examinará cuál ha sido la actuación y pronunciamiento de los jueces al encontrarse frente a este trámite incidental, de modo tal que se distingan sus posibles deficiencias y problemáticas.

Para entender la referida problemática resulta importante remitirse al numeral I de este texto. Como se expuso anteriormente, existen dos partes constitutivas del fallo de tutela: una, la decisión de amparo, es decir, si se concede o no el mecanismo de amparo; otra, la orden específica que ampara el derecho constitucional fundamental alegado. Para tal efecto, el juez fija un plazo perentorio para que se dé cumplimiento a lo dispuesto en el fallo de tutela, el cual normalmente es de cuarenta y ocho horas ${ }^{35}$ después del fallo, a no ser que la naturaleza del asunto requiera de más tiempo ${ }^{36}$.

Teniendo en cuenta este término, la parte accionada, a partir de la notificación del fallo, debe

35 . Artículo 60 de la Ley 4 de 1913; el Código de Régimen Político y Municipal define las horas hábiles y la forma de su conteo.

36 . Corte Constitucional. Sentencias T-116 de 1993, T-014 de 1994 T-125 de 1995 y T-081 de 1998. proceder a cumplir la orden contenida en la decisión de tutela encaminada a la protección de los derechos fundamentales, pues tal y como lo ha establecido la Corte Constitucional:

el incumplimiento de la decisión conlleva una violación sistemática de la Carta. Por una parte, en cuanto frustra la consecución material de los fines esenciales del Estado, como son la realización efectiva de los principios, derechos y deberes consagrados en la Carta, el mantenimiento de la convivencia pacífica y la vigencia de un orden justo (Preámbulo, arts. $1^{\circ}$ y $\left.2^{\circ}\right)$. Y por la otra, en cuanto dicha omisión contraría, además de las normas constitucionales que regulan la acción de tutela y el derecho infringido, también aquellas que reconocen en el valor de la justicia y en los derechos al debido proceso y al acceso efectivo a la administración de justicia, pilares fundamentales del modelo de Estado Social de Derecho (arts. 29, 86 y 230)"37.

Resulta claro entonces que el accionado tiene el deber constitucional de cumplir la orden de tutela, pues de incumplirse se quebranta el objetivo dispuesto en el artículo 86 de la Carta Política: la protección inmediata de los derechos constitucionales de las personas, lo cual obstaculizaría no solo los derechos al debido proceso y acceso a la administración de justicia, sino que además "contraviene notablemente el valor de la cosa juzgada constitucional y con ello la seguridad jurídica que le es inmanente, ya que la omisión de su cumplimiento afecta la garantía de confianza que tienen los ciudadanos sobre cuál ha de ser la actuación de las autoridades

37 . Corte Constitucional. Sentencia T-606 de 2011. 
o de los particulares frente a situaciones derivadas de la aplicación del derecho vigente"38.

Es necesario recalcar que la obligación de la parte accionada de cumplir lo dispuesto en el amparo constitucional no proviene solamente de la Carta Política y los derechos derivados de esta, también encuentra su fundamento en el artículo 2 del Pacto Internacional de Derechos Civiles y Políticos y el artículo 25 de la Convención Americana de Derechos Humanos. Los anteriores fueron incorporados al orden interno mediante la Ley 74 de 1968 y la Ley 16 de 1972, respectivamente, lo cual no solamente exige, como se expuso en el primer capítulo, la implementación de un recurso sencillo, efectivo y breve que ampare los derechos fundamentales, sino también obliga a las autoridades competentes a cumplir las decisiones en que se haya estimado procedente el recurso.

Frente a lo anterior, cabe mencionar que el cumplimiento del accionado debe estar garantizado por mecanismos jurídicos a través de los cuales el juez asegure el cumplimiento de la orden de amparo, pues esta "sería inocua si no existieran mecanismos ágiles, eficaces y oportunos al alcance del juez para coaccionar u obligar a la autoridad o persona que violó o desconoció un derecho fundamental, y destinatario de una orden, para que cumpla con lo dispuesto por el funcionario judicial y restablezca, en los términos fijados por él, el derecho violado o amenazado $^{39}$. Al respecto, en la regulación de la acción de tutela se instituyeron los mecanismos para

\footnotetext{
38 . Corte Constitucional. Auto 010 de 2004.

hacer efectivo el cumplimiento del fallo de tutela y las sanciones derivadas de su incumplimiento.

Así pues, se estableció en los artículos 27 y 52 del Decreto 2591 de 1991 dos mecanismos de cumplimiento de la orden del fallo de tutela. Por una parte, una obligación constitucional al juez para que adopte todas las medidas necesarias con el fin de que haya cumplimiento del fallo $y$, por otro lado, la posibilidad del agraviado para solicitar que se sancione por desacato al sujeto que incumpla la orden del fallo de tutela.

\section{A. El cumplimiento del fallo de tutela según lo dispuesto en el artículo 27 del Decreto 2591 de 1991}

Como se anotó anteriormente, el Presidente de la República, revestido de facultades extraordinarias, dispuso en el artículo 27 del Decreto 2591 de $1991^{40}$ un mecanismo detallado de carácter obligatorio para garantizar el cumplimiento de la orden proferida por el juez constitucional, por medio del cual el juez ${ }^{41}$ debe tomar las medidas necesarias para que haya

40 Artículo 27. Cumplimiento del fallo. Proferido el fallo que concede la tutela, la autoridad responsable del agravio deberá cumplirla sin demora.

Si no lo hiciere dentro de las cuarenta y ocho horas siguientes, el juez se dirigirá al superior del responsable y le requerirá para que lo haga cumplir y abra el correspondiente procedimiento disciplinario contra aquél. Pasadas otras cuarenta y ocho horas, ordenará abrir proceso contra el superior que no hubiere procedido conforme a lo ordenado y adoptará directamente todas las medidas para el cabal cumplimiento del mismo. El juez podrá sancionar por desacato al responsable y al superior hasta que cumplan su sentencia.

Lo anterior sin perjuicio de la responsabilidad penal del funcionario en su caso.

En todo caso, el juez establecerá los demás efectos del fallo para el caso concreto y mantendrá la competencia hasta que esté completamente restablecido el derecho o eliminadas las causas de la amenaza".

Corte Constitucional. Sentencia T-611 de 2011 
cumplimiento de lo dispuesto en la orden de tutela. Por consiguiente, si la parte accionada no cumple con la orden del fallo de tutela dentro de las cuarenta y ocho (48) horas siguientes a su notificación, se recurrirá al superior jerárquico ${ }^{42}$ para que dentro de otras cuarenta y ocho horas (48) siguientes haga cumplir el fallo a la parte accionada renuente, y abra el correspondiente proceso disciplinario en su contra. En caso de que el superior tampoco cumpla, pasadas otras cuarenta y ocho (48) horas el juez podrá ordenar abrir proceso en su contra, y adoptar todas las medidas necesarias para el cabal cumplimiento de la orden. Así mismo, el citado artículo faculta al juez para sancionar por desacato tanto al responsable como al superior, hasta que cumplan con su sentencia ${ }^{43}$.

En relación con las medidas que debe adoptar el juez para que haya cabal cumplimiento de la orden de amparo, la jurisprudencia constitucional ha reiterado en diferentes ocasiones ${ }^{44}$ que este, dentro de su actividad judicial, debe tomar todas aquellas medidas conducentes para obtener la protección real y efectiva de los derechos fundamentales afectados, sin perjuicio de las sanciones de desacato que se impongan, ${ }^{45}$

42 . La Corte Constitucional, en sentencia T-942 de 2000, determinó que si el funcionario no tiene superior jerárquico se debe recurrir a la Procuraduría General de la Nación.

43 . Tal como se expresó en sentencia T-763 de 1998, "el juez encargado de hacer cumplir el fallo PODRÁ (así lo indica el artículo 27 del Decreto 2591 de 1991) sancionar por desacato. Es pues esta una facultad optativa, muy diferente al cumplimiento del fallo y que en ningún instante es supletoria de la competencia para la efectividad de la orden de tutela. Pueden, pues, coexistir al mismo tiempo el cumplimiento de la orden y el trámite del desacato, pero no se pueden confundir el uno (cumplimiento del fallo) con el otro (el trámite de desacato)".

44

. Corte Constitucional. Sentencias T-553 de 2002 y T-512 de 2011.

45 pues, como se anotó anteriormente, el cumplimiento de la orden del fallo es una obligación constitucional para el juez.

Ahora bien, con referencia al tipo de responsabilidad que debe observarse en este procedimiento, la Corte Constitucional ha distinguido que en este caso el juez constitucional debe analizar la responsabilidad objetiva de la parte accionada. Al respecto, no se hace análisis si en el comportamiento hay nexo causal sustentado en la culpa o dolo, sino simplemente si la orden se cumplió o no ${ }^{46}$.

Conforme a lo dicho, se entiende entonces que el objetivo del trámite de cumplimiento es: (i) "analizar objetivamente si la orden de amparo se ha cumplido (...) y, en caso de que no sea así", (ii) adoptar "todas las medidas necesarias para el cabal cumplimiento" 47 pues, como ya se dijo, se busca otorgar poderes amplios al juez constitucional $^{48}$ para lograr el cumplimiento material y objetivo de la orden de protección de los derechos invocados ${ }^{49}$. Por lo expuesto, el juez constitucional no puede, en virtud de la discrecionalidad, dejar de actuar para que haya cumplimiento de la orden ${ }^{50}$, sino, por el contrario, debe tomar todas las medidas necesarias para el restablecimiento del derecho, pues como se anotó, tiene una obligación irrenunciable para

\footnotetext{
46 . Corte Constitucional. Auto 106 de 2012.

47 . Corte Constitucional. Sentencia T-661 de 2011

48 . En autos 178 de 2005, 249 de 2006, 139 de 2011, se estableció que es el juez de primera instancia quien conserva la competencia para asegurar el cumplimiento de la orden dispuesta en el fallo de tutela.

49 . Corte Constitucional. Sentencia T-123 de 2010.

50 . Corte Constitucional. Sentencia T-763 de 1998
} 
hacer cumplir lo dispuesto en la orden de protección del fallo de tutela.

\section{B. El trámite incidental de desacato como mecanismo de cumplimiento de la acción de tutela}

El legislador extraordinario, previendo que el fallo judicial no se cumpliera, reguló en los artículos 27 y 52 del Decreto 2591 de 1991 la posibilidad de sancionar por medio de trámite incidental de desacato a la autoridad o el particular accionado renuente al cumplimiento del fallo de tutela. ${ }^{51}$ En este sentido estableció:

Artículo 27. (...) El juez podrá sancionar por desacato al responsable y al superior hasta que cumplan su sentencia (...)

Artículo 52. Desacato. La persona que incumpliere una orden de un juez proferida con base en el presente Decreto, incurrirá en desacato sancionable con arresto hasta de seis (6) meses y multa hasta de veinte (20) salarios mínimos mensuales, salvo que en este Decreto ya se hubiere señalado una consecuencia jurídica distinta y sin perjuicio de las sanciones penales a que hubiere lugar.

La sanción será impuesta por el mismo juez mediante trámite incidental y será consultada al superior jerárquico quien decidirá dentro de los tres días siguientes si debe revocarse la sanción.

Conforme a lo dicho, dentro de las medidas que puede adoptar el juez constitucional para que haya cumplimiento de la orden del fallo de tute-

51

Corte Constitucional. Sentencia T-053 de 2005 la se estableció el desacato. De esta forma, se creó una figura accesoria, de origen legal, inscrita en el ejercicio del poder jurisdiccional sancionatorio ${ }^{52}$, por medio de la cual se sancionaría al sujeto obligado a cumplir la orden cuando fuese probado su desinterés y negligencia. En este caso, el juez en ejercicio del poder sancionatorio ${ }^{53}$ y coercitivo ${ }^{54}$, previo a un trámite incidental, podrá imponer las sanciones necesarias si se comprueba la responsabilidad subjetiva, consistente en que la parte accionada no tuvo la voluntad de cumplir con la orden consignada en la sentencia ${ }^{55}$.

De esta manera, con el fin de persuadir para que se cumpla la orden del fallo de tutela, el juez puede sancionar con arresto o multa a la parte que la incumpla. Respecto a lo anterior, cabe aclarar que la Corte Constitucional ha establecido que esta es una medida de carácter correccional $^{56}$; por consiguiente, el principal propósito de este trámite es lograr la eficacia en el cumplimiento de las órdenes impartidas por el juez de amparo ${ }^{57}$, razón por la cual si en el transcurso del trámite se verifica que el fallo se cumplió no habrá sanción ${ }^{58}$.

. Corte Constitucional. Sentencia T-123 de 2010.

53 . Corte Constitucional. Sentencia T-188 de 2002

$54 \quad$ lbid.

55 . Corte Constitucional. Sentencia T-171 de 2009.

56 . Corte Constitucional. Sentencia C-092 de 1997

57 . Corte Constitucional. Sentencia C-243 de 1996

58 . Corte Constitucional. Sentencia T-171 de 2009
} 
Ahora bien, la Corte Constitucional ha definido que el incidente de desacato es un mecanismo de creación legal, que puede iniciarse a petición de la parte interesada ${ }^{59}$, el cual se adelantará cuando se alegue el incumplimiento de una orden judicial impartida al interior de una sentencia de tutela que haya hecho tránsito a cosa juzgada ${ }^{60}$. Por lo anterior, se ha instituido como un instrumento procesal para garantizar el acceso a la administración de justicia del accionante (Art. $229 \mathrm{CP}$ ), pues este "implica no solo la posibilidad de poner en movimiento, a través de la formulación de una pretensión, la actividad jurisdiccional del Estado, sino la de obtener una pronta resolución de la misma, y que la decisión estimatoria de la pretensión logre su plena eficacia mediante el mecanismo de la ejecución de la respectiva sentencia, que tienda a su adecuado cumplimiento (Olano, 2009, p. 343).

\section{Trámite del incidente de desacato}

Teniendo un concepto somero sobre el incidente de desacato, se debe analizar ahora el trámite previsto para este mecanismo de cumplimiento.

59 . De acuerdo con los numerales 1, 2 y 7 del artículo 277 de la Constitución Política, el Ministerio Público podrá intervenir para que haya cabal cumplimiento de la orden del fallo de tutela, pues el procurador tiene dentro sus funciones: a) vigilar el cumplimiento de las decisiones judiciales, b) intervenir en los procesos y ante las autoridades judiciales o administrativas, cuando sea necesario, en defensa de los derechos y garantías fundamentales, c) proteger los derechos humanos y asegurar su efectividad, con el auxilio del Defensor del Pueblo. En concordancia con lo anterior, el artículo 288 de la Constitución Política establece que el Defensor del Pueblo tiene dentro de sus funciones: a) Orientar e instruir a los habitantes del territorio nacional y a los colombianos en el exterior en el ejercicio y defensa de sus derechos ante las autoridades competentes o entidades de carácter privado, y b) interponer las acciones de tutela, sin perjuicio del derecho que asiste a los interesados.
En primera instancia debe decirse que el trámite incidental de la acción de tutela puede equipararse con el instrumento previsto en el artículo 39, numeral $1^{\circ}$ del Código de Procedimiento Civil, por el cual se le concede al juez civil potestades para que imponga sanciones de naturaleza sancionatoria ${ }^{61}$. Sin embargo, debe precisarse que la Corte Constitucional ha afirmado que el incidente de desacato tiene como fin esencial que haya cumplimiento de lo ordenado y no solo la imposición de medidas sancionatorias. Así, dispuso en sentencia T-171 de 2009 que:

el principal propósito de este trámite se centra en conseguir que el obligado obedezca la orden impuesta en la providencia originada a partir de la resolución de un recurso de amparo constitucional. Por tal motivo, debe precisarse que la finalidad del mencionado incidente no es la imposición de una sanción en sí misma, sino que debe considerarse como una de las formas de buscar el cumplimiento de la respectiva sentencia. ${ }^{62}$

De acuerdo con las consideraciones expuestas, y teniendo en cuenta que el juez tiene el deber constitucional de hacer cumplir las órdenes dispuestas en sentencia de tutela, se debe estudiar el proceder del juez constitucional cuando se encuentra ante un trámite incidental de desacato. Para analizar lo anterior, ha de recordarse que la jurisprudencia constitucional, refiriéndose al texto del artículo 52 del Decreto 2591 de 1991, señaló en sentencia T-554 de 1996:

61 . Corte Constitucional. Sentencia C-203 de 2011; véase también el auto 083 de 2012.

62 . Corte Constitucional. Sentencia T-171 de 2009 
El texto transcrito es completo en el sentido de que señala, no sólo el contorno de la figura del desacato, al establecer las circunstancias bajo las cuales éste se conforma, y las sanciones que el mismo conlleva, sino toda la estructura procesal de la actuación que debe surtirse para la declaración de que una persona ha incurrido en desacato y la imposición de la correspondiente sanción, al determinarse el medio que debe utilizarse, esto es, el trámite de un incidente, el juez competente, y el mecanismo para revisar y controlar la decisión sancionatoria.

No se requiere, por tanto, acudir a otras normas para integrar el trámite a que debe someterse la actuación respectiva, ni siquiera a los principios generales del sistema incidental que regula el Código de Procedimiento Civil, de manera que resulta inoficioso remitirse a otros textos normativos, so pretexto de llenar un vacío, porque, justamente, en este caso la disposición en comento es, como se ha dicho, suficiente o completa, esto es, regula íntegramente la materia. La sencillez de las fórmulas procesales para el trámite de la acción de tutela, la celeridad, la eficiencia y la eficacia con que ésta debe ser tramitada con miras a hacer efectivos los derechos fundamentales y a asegurar el cumplimiento de los fallos de tutela, que revelan las normas constitucionales y legales que la regulan, en forma integral, hacen innecesario acudir a procesalismos rígidos y extremos pertenecientes a otros estatutos, salvo en circunstancias excepcionales en que se advierta un evidente vacío procesal. Y aún en este caso, las normas procesales a las cuales se acuda para la integración normativa deben estar acordes o ser compatibles con la filosofía propia de dicha acción.

En virtud de lo anterior, podría suponerse, entonces, que el juez constitucional debe tramitar el incidente de desacato en concordancia con lo dispuesto en el artículo 52 del Decreto 2591 de 1991, sin embargo, en la práctica se ha evidenciado que al no encontrarse en el precepto en mención las reglas específicas o términos a seguir, los jueces han asimilado el trámite incidental de desacato según las normas dispuestas en el Código de Procedimiento Civil. Lo anterior no ha sido aplicado de modo discrecional o arbitrario, sino siguiendo lo establecido en el artículo 4 del Decreto 306 de 1992, el cual dispone que para la interpretación de las disposiciones sobre trámite de la acción de tutela previstas por el Decreto 2591 de 1991, se deben aplicar los principios generales del Código de Procedimiento Civil en todo aquello que no sea contrario a dicho decreto.

Con fundamento en lo expuesto, puede verse entonces que en el caso del trámite incidental de desacato el juez constitucional debe remitirse a la regulación del incidente de desacato prevista en el artículo 137 del Código de Procedimiento Civil ${ }^{63}$. Esto por cuanto, aunque ha

63 . "Artículo 137. Código de Procedimiento Civil. Los incidentes se propondrán y tramitarán así:

1. El escrito deberá contener lo que se pide, los hechos en que se funden y la solicitud de las pruebas que se pretenda aducir, salvo que éstas figuren ya en el proceso.

Al escrito deberán acompañarse los documentos y pruebas anticipadas que se pretenda hacer valer y que se encuentren en poder del peticionario.

2. Del escrito se dará traslado a la otra parte por tres días, quien en la contestación pedirá las pruebas que pretenda hacer valer y acompañará los documentos y pruebas anticipadas que se encuentren en su poder, en caso de que no obren en el expediente.

3. Vencido el término del traslado, el juez decretará la práctica de las pruebas pedidas que se considere necesarias y de las que ordene de oficio, para lo cual señalará, según el caso, un término de diez días o dentro de él, la fecha y hora de la audiencia o diligencia; no habiendo pruebas qué practicar, decidirá el incidente.

4. Por regla general los incidentes no suspenden el curso del proceso, pero la sentencia no se pronunciará mientras haya alguno pendiente, 
sido objeto de discusión por la Corte Constitucional, en la práctica se sigue evidenciando que al no encontrarse un trámite detallado sobre el incidente de desacato, el juez lo asimila con los incidentes de la jurisdicción ordinaria.

Teniendo en cuenta que la sanción debe estar precedida por un trámite incidental, la Corte Constitucional ha establecido unos requisitos mínimos que debe cumplir el juez para garantizar la eficacia del derecho al debido proceso del sujeto contra quien se ejerce el trámite. En este sentido dispuso que el juez debe:

(i) comunicar al incumplido sobre la iniciación del incidente de desacato, con el fin de darle la oportunidad para que informe la razón por la cual no ha dado cumplimiento a la orden y presente sus argumentos de defensa. En dicho informe el responsable podrá alegar dificultad grave para cumplir la orden, pero solo en el evento en que esta sea de imposible cumplimiento, lo cual debe demostrar por cualquier medio probatorio; (ii) practicar las pruebas que se le soliciten al juez de conocimiento, al igual que aquellas que considere conducentes y pertinentes para adoptar la decisión; (iii) notificar la providencia que resuelva son indispensables para adoptar la decisión; y, en caso de que haya lugar a ello, (iv) remitir el expediente en consulta ante el superior.

Ahora bien, respecto a la competencia para conocer del trámite incidental de desacato, la

sin perjuicio de los que se deban resolver en ella y de lo dispuesto en los artículos 354 y 355.

5. Sobre la procedencia de las apelaciones que se interpongan en el curso de un incidente, se resolverá en el auto que conceda la apelación que se interponga contra el auto que decida el incidente. Si no se apela éste, aquéllas se tendrán por no interpuestas". jurisprudencia constitucional, después de algunas discrepancias respecto de cuál era la autoridad encargada de velar por el cumplimiento de una sentencia de tutela y tramitar un incidente de desacato, de ser necesario, determinó que dicha atribución está radicada en el juez de primera instancia. No resulta relevante entonces si la tutela fue concedida por el juez de segunda instancia o incluso por la Corte Constitucional en sede de revisión, para que el juez de primera instancia deba tramitar el incidente de desacato. Al respecto, mediante auto 136A de 2002 la Corte Constitucional expuso:

En Conclusión, la Sala encuentra que el juez de primera instancia (singular o plural), que haya conocido el trámite de tutela, es en todo caso el competente para conocer del trámite incidencial por desacato. Esta interpretación tiene fundamento en los siguientes aspectos: (i) Obedece a una interpretación sistemática del decreto 2591 de 1991, (ii) genera claridad en términos de seguridad jurídica, al desarrollar el principio de igualdad en los procedimientos judiciales, (iii) está en armonía con el principio de inmediación del trámite de tutela y, (iv) protege la eficacia de la garantía procesal en que consiste el grado jurisdiccional de consulta.

\section{La responsabilidad subjetiva como medio para determinar si se debe iniciar trámite incidental de desacato}

Con fundamento en lo expuesto, la jurisprudencia constitucional ha establecido unos criterios para determinar si se debe sancionar por desacato a la parte accionada, pues no se reduce a que haya incumplimiento del fallo. Conforme a lo dicho, debe empezarse a estudiar cuándo 
procede el desacato. En sentencia T-459 de 2003 la Corte Constitucional determinó que:

se entiende que el desacato procede cuando no ha sido cumplida la orden dictada en un faIlo de tutela, cuando el cumplimiento ha sido insuficiente o incompleto, cuando no han sido obedecidas otras decisiones tomadas por el juez en el curso del proceso, cuando no se obedece la orden judicial dada al demandado, de no volver a incurrir en las conductas que dieron origen a la vulneración de los derechos fundamentales, o cuando el demandado no cumple dentro de los términos señalados por la providencia judicial. ${ }^{64}$

Así las cosas, el juez constitucional al tramitar el incidente de desacato debe proceder a buscar la presencia de elementos que demuestren la responsabilidad subjetiva de quien incumplió65 lo dispuesto en fallo de tutela, pues no en todas las ocasiones donde haya incumplimiento se debe proceder a abrir incidente de desacato, ya que "dentro del proceso debe aparecer probada la negligencia de la persona que desconoció el referido fallo, lo cual conlleva a que no pueda presumirse la responsabilidad por el sólo hecho del incumplimiento" ${ }^{66}$. Para tal efecto, se debe establecer "la existencia de responsabilidad subjetiva del accionado y cuál debe ser la sanción adecuada - proporcionada y razonable- a Ios hechos" ${ }^{67}$.

64 . Corte Constitucional. Sentencia T-459 de 2003

65 . Corte Constitucional. Sentencia T-171 de 2009

66 . Corte Constitucional. Sentencia T-1113 de 2005.

67

. Corte Constitucional. Sentencia T-171 de 2009.
Con lo anterior podrá determinar su tipo de responsabilidad y, con base en ello, analizar si en el caso se evidencia un incumplimiento parcial o integral de la respectiva orden de tutela, pues "la mera adecuación de la conducta del accionado con base en la simple y elemental relación de causalidad material conlleva a la utilización del concepto de responsabilidad objetiva, la cual está prohibida por la Constitución y la Ley en materia sancionatoria. Esto quiere decir que entre el comportamiento del demandado y el resultado siempre debe mediar un nexo causal sustentado en la culpa o el dolo"68.

¿Qué debe entonces hacer el juez constitucional para determinar la responsabilidad subjetiva de la parte accionada? El juez, en uso de sus facultades jurisdiccionales debe proceder a verificar: (1) a quién estaba dirigida la orden; (2) cuál fue el término otorgado para ejecutarla; y (3) el alcance de esta. Lo anterior con el objeto de concluir si el destinatario de la orden cumplió de forma oportuna y completa la conducta esperada ${ }^{69}$. Adicionalmente, el juez del desacato debe verificar si efectivamente se incumplió la orden impartida a través de la sentencia de tutela y, de existir el incumplimiento, debe identificar si fue integral o parcial $^{70}$ y establecer si existe un nexo causal sustentado en culpa o dolo entre el comportamiento de la parte accionada y el resultado ${ }^{71}$.

\footnotetext{
68 . Corte Constitucional. Sentencias T-553 de 2002 y T-368 de 2005.

69 . Corte Constitucional. Sentencia T-1113 de 2005.

70 . Corte Constitucional. Sentencia T-171 de 2009.

71 . Corte Constitucional. Sentencia T-1113 de 2005.
} 
Para tal efecto, la Corte Constitucional ha establecido que al momento de analizar la responsabilidad subjetiva debe examinarse si, en el caso concreto, se está bajo situaciones especiales que puedan Ilegar a ser causales exonerativas de responsabilidad. Así pues, debe tenerse en cuenta si ocurrieron circunstancias de fuerza mayor, caso fortuito o imposibilidad absoluta jurídica o fáctica para cumplir, enmarcadas dentro del principio de buena fe de la parte accionada ${ }^{72}$. En este orden de ideas, no se podrá abrir incidente de desacato cuando: (i) la orden impartida por el juez de tutela no ha sido precisa -porque no se determinó quién debe cumplirla- o su contenido es difuso y, (ii) cuando el obligado de buena fe quiere cumplir la orden pero no se le ha dado la oportunidad de hacerlo ${ }^{73}$.

Es importante tener presente que el juez no puede olvidar, en ningún momento, que aunque debe indagar sobre la responsabilidad subjetiva de la parte accionante, ha de hacerlo en concordancia con los principios constitucionales del ordenamiento jurídico colombiano. En este sentido, debe tener presente lo dispuesto en el artículo 29 de la Carta Política por el cual se dispone que: "Toda persona se presume inocente mientras no se le haya declarado judicialmente culpable." Así pues, las únicas faltas que pueden ser sancionables disciplinariamente a título de dolo o culpa deben haber sido desarrolladas en un proceso "con las garantías propias del derecho disciplinario y, en general, del debido pro-

72 . Corte Constitucional. Sentencia T-368 de 2005.

73 . Corte Constitucional. Sentencia C-728 de 2000. ceso, y que dentro de éste se haya establecido la responsabilidad del disciplinado" ${ }^{74}$.

En concordancia con lo anterior, la jurisprudencia constitucional ha determinado que dentro de todo el trámite del incidente de desacato se deben salvaguardar las garantías constitucionales al derecho al debido proceso y defensa de la persona contra quien se tramita el incidente. En virtud de lo anterior, y tal como se explicó en el acápite del "trámite del incidente de desacato" el juez también tiene el deber de comunicar al incumplido sobre la iniciación de este para darle la oportunidad de que informe la razón por la cual no ha dado cumplimiento a la orden y presente sus argumentos de defensa.

Ahora bien, si como resultado del análisis del juez resulta que no hay responsabilidad subjetiva, no se impondrá sanción alguna y ahí terminará el trámite, pues no hay ningún tipo de recurso para la decisión, ni siquiera recurso de apelación, tal y como lo ha expresado la jurisprudencia constitucional ${ }^{75}$. En caso que sí prospere el incidente de desacato habrá grado jurisdiccional de consulta, en el cual el superior

74 . Corte Constitucional, Sentencia C-243 de 1996. "Es por ello que la correcta interpretación y alcance del artículo 52 del Decreto 2591 de 1991, parcialmente demandado de inexequibilidad, no puede ser otro que el que se deduce de su tenor literal y del sentido natural y obvio de sus palabras: es decir, consagra un trámite incidental especial, que concluye con un auto que nunca es susceptible del recurso de apelación, pero que si dicho auto es sancionatorio, debe ser objeto del grado de jurisdicción llamado consulta, cuyo objeto consiste en que el superior jerárquico revise si está correctamente impuesta la sanción, pero que en sí mismo no se erige como un medio de impugnación. Y ello es así por cuanto el trámite de la acción de tutela es un trámite especial, preferente y sumario que busca la protección inmediata de los derechos fundamentales, lo cual implica una especial relievancia del principio de celeridad". 
jerárquico del juez de primera instancia evalúa si se analizó bien dicho incidente.

\section{Inconformidad con la decisión del trámite incidental de desacato y sus recursos}

Al regirse el incidente de desacato por las normas especiales del Decreto 2591 de 1991, cuando la decisión del incidente sea desfavorable al accionante este no puede agotar ningún recurso para elevar su inconformismo ${ }^{76}$. En este sentido la Corte Constitucional estableció:

Es por ello que la correcta interpretación y alcance del artículo 52 del Decreto 2591 de 1991, parcialmente demandado de inexequibilidad, no puede ser otro que el que se deduce de su tenor literal y del sentido natural y obvio de sus palabras: es decir, consagra un trámite incidental especial, que concluye con un auto que nunca es susceptible del recurso de apelación, pero que si dicho auto es sancionatorio, debe ser objeto del grado de jurisdicción Ilamado consulta, cuyo objeto consiste en que el superior jerárquico revise si está correctamente impuesta la sanción, pero que en sí mismo no se erige como un medio de impugnación. $Y$ ello es así por cuanto el trámite de la acción de tutela es un trámite especial, preferente y sumario que busca la protección inmediata de los derechos fundamentales, lo cual implica una especial relevancia del principio de celeridad. ${ }^{77}$

Teniendo en cuenta lo anterior, puede establecerse entonces que cuando la decisión es favorable para el accionante procede el grado

76

. Corte Constitucional. Sentencia T-572 de 1996.

77

Corte Constitucional. Sentencia C-246 de 1996 jurisdiccional de consulta ante el superior jerárquico en efecto suspensivo. Es importante precisar que el grado de consulta procede sin necesidad de solicitud por alguna de las partes de la acción de tutela, pues es un "mecanismo automático que lleva al juez de nivel superior a establecer la legalidad de la decisión adoptada por el inferior, generalmente con base en motivos de interés público o con el objeto de proteger a la parte más débil en la relación jurídica de que se trata" 78.

Con base en lo mencionado, se debe tener presente que el juez constitucional, en este caso, se limita a analizar si hubo legalidad del auto consultado, por tanto, si en grado de consulta se determina que no ha existido incumplimiento alguno deberá proceder a revocar la sanción por desacato ${ }^{79}$ y si considera que sí hubo incumplimiento pero que la sanción impuesta por el juez de primera instancia no es la correcta, este podrá modificarla ${ }^{80}$.

\section{Los incidentes de desacato no deben ser enviados a la Corte Constitucional para su eventual revisión}

A diferencia de lo que sucede con las decisiones de la acción de tutela, los incidentes de desacato no deben ser enviados a la Corte Constitucional para su eventual revisión, pues esta carece de competencia para ello en virtud de las facultades otorgadas por el artículo 241 de la
78 . Ibid.
79 . Corte Constitucional. Sentencia T-086 de 2003.
80 . Corte Constitucional. Auto 005 de 1994 
Carta Política. Tal y como se indicó en auto 005 de 1994:

la competencia de la Corte Constitucional en materia de Acciones de Tutela radica únicamente en revisar "eventualmente" los fallos de tutela proferidos por los jueces de la República -numeral 9o. del artículo 241 de la Carta Política y artículos 31 a 34 del Decreto 2591 de 1991-, y no en revisar la decisión proferida por un juez dentro de un incidente por desacato. En ningún caso puede interpretarse el artículo 52 del Decreto 2591 de 1991, en el sentido de que esté facultada la Corte Constitucional para intervenir en el proceso incidental de imposición de sanciones por desacato a una orden de un juez proferida dentro de un proceso de tutela"81.

\section{5. ¿Cómo están fallando los jueces constitucionales al encontrarse frente al trámite incidental de desacato? Casos concretos}

Habiendo expuesto la naturaleza, trámite y regulación del incidente de desacato, resulta ahora pertinente exponer algunos casos concretos con el fin de evaluar el proceder de los jueces constitucionales al enfrentarse a un trámite incidental de desacato. Para lo anterior, se procedió a consultar los procesos de acción de tutela del semestre 2012-2 del Consultorio Jurídico de la Universidad de los Andes, y se seleccionaron los que han sido objeto de solicitud de desacato. Por otro lado, con la ayuda del doctor Santiago Aristizábal, abogado de la Asociación Colombiana de Pacientes con Enfermedades de Depósito Lisosomal -ACOPEL ${ }^{\square}$ - se pudo consultar varios procesos de tutela de pacientes ayudados por esta Asociación, en los que se evidencia no solo la negligencia de las entidades promotoras de salud para prestar un servicio mínimo de vida, sino también el actuar de los jueces al enfrentarse al incumplimiento de una orden de un fallo de tutela.

A continuación se exponen los procesos estudiados y se especifican las siguientes categorías: i) accionante, ii) accionado, iii) derecho fundamental alegado, iv) juzgado, v) orden del juez y vi) solicitud de desacato y decisión del juez constitucional.

81 . Entidad sin ánimo de lucro fundada en 1997, registrada en Cámara de Comercio y con vigilancia de la Alcaldía Mayor de Bogotá. Ante las múltiples barreras que enfrentan las personas con diagnóstico de enfermedades poco frecuentes como las de depósito lisosomal, sobre las que hay un gran desconocimiento incluso por parte del cuerpo médico, ACOPEL se fijó como propósito ayudar a esta población de muy diversas condiciones y alta vulnerabilidad por sus condiciones de salud, contribuyendo en la eliminación de obstáculos que van desde el diagnóstico hasta el tratamiento. Su objetivo principal es ayudar a los pacientes con enfermedades de depósito lisosomal, en la búsqueda de soluciones para su tratamiento integral, brindando la asistencia requerida a estos, sus familiares, cuerpo médico, instituciones de salud e interesados en la detección, el conocimiento, manejo y tratamiento de las enfermedades de depósito lisosomal. Para mayor información, ver: http://www.acopel.org.co/ 


\begin{tabular}{|c|c|c|c|c|c|}
\hline ACCIONANTE & ACCIONADO & $\begin{array}{c}\text { DERECHO } \\
\text { FUNDA- } \\
\text { MENTAL }\end{array}$ & JUZGADO & ORDEN & DESACATO \\
\hline $\begin{array}{l}\text { Aleida } \\
\text { Bohórquez } \\
\text { Otálora. } \\
\text { Agenciada } \\
\text { por Olga } \\
\text { Lucía Bohór- } \\
\text { quez }\end{array}$ & $\begin{array}{l}\text { ECOOPSOS } \\
\text { EPS-S }\end{array}$ & Salud & $\begin{array}{l}\text { Juzgado } 26 \\
\text { Civil Mu- } \\
\text { nicipal de } \\
\text { Bogotá }\end{array}$ & $\begin{array}{l}\text { El } 22 \text { de febrero } \\
\text { de } 2010, \text { se orde- } \\
\text { nó a la EPS efec- } \\
\text { tuar la entrega } \\
\text { del medicamento } \\
\text { dentro de las } 24 \\
\text { horas siguientes. }\end{array}$ & $\begin{array}{l}\text {-Teniendo en cuenta que habían } \\
\text { pasado tres meses y el medicamen- } \\
\text { to no había sido suministrado, el } 20 \\
\text { de mayo } 2010 \text { se solicitó sancionar } \\
\text { por desacato a la accionada. } \\
\text { - Diez meses después, el } 23 \text { de } \\
\text { noviembre de } 2010, \text { se ordenó el } \\
\text { cierre del incidente pues la entidad } \\
\text { había procedido a cumplir. } \\
\text { - El } 26 \text { de mayo de } 2011 \text {, el accio- } \\
\text { nante tuvo que volver a solicitar } \\
\text { sanción por desacato. } \\
\text { - Siendo noviembre de } 2012 \text { el } \\
\text { juzgado ha mandado tres requeri- } \\
\text { mientos, sin pronunciarse sobre el } \\
\text { desacato. }\end{array}$ \\
\hline $\begin{array}{l}\text { Kevin Stiven } \\
\text { Arias Díaz. } \\
\text { Agenciado } \\
\text { por Diana } \\
\text { Lorena Díaz } \\
\text { Yaguará }\end{array}$ & $\begin{array}{l}\text { CAPRECOM } \\
\text { EPS }\end{array}$ & $\begin{array}{l}\text { Salud, } \\
\text { vida, } \\
\text { igualdad y } \\
\text { dignidad } \\
\text { humana }\end{array}$ & $\begin{array}{l}\text { Juzgado } 4 \text { o } \\
\text { Penal del } \\
\text { Circuito de } \\
\text { Ibagué }\end{array}$ & $\begin{array}{l}\text { El } 3 \text { mayo } 2011 \\
\text { se ordenó al ge- } \\
\text { rente de la EPS } \\
\text { que en las } 48 \\
\text { horas siguientes, } \\
\text { autorizara al niño } \\
\text { a "imigluzeraza" y } \\
\text { tratamiento inte- } \\
\text { gral. }\end{array}$ & $\begin{array}{l}\text { - Habiendo pasado dos meses } \\
\text { desde que se dio la orden no se } \\
\text { había cumplido con el tratamiento } \\
\text { integral, por tanto se procedió a } \\
\text { solicitar apertura de incidente de } \\
\text { desacato el } 3 \text { de julio de } 2011 . \\
\text { - El } 4 \text { de agosto de } 2011 \text {, después } \\
\text { de mandar cuatro requerimientos, } \\
\text { se falló sobre desacato negándolo } \\
\text { por hecho superado. }\end{array}$ \\
\hline
\end{tabular}




\begin{tabular}{|c|c|c|c|c|c|}
\hline $\begin{array}{l}\text { Aleida } \\
\text { Carvajal }\end{array}$ & $\begin{array}{l}\text { Unión Tempo- } \\
\text { ral Magisterio } \\
\text { Sur. EMCOSA- } \\
\text { LUD }\end{array}$ & $\begin{array}{l}\text { Salud y } \\
\text { vida digna }\end{array}$ & $\begin{array}{l}\text { Juzgado 3o } \\
\text { Penal Mu- } \\
\text { nicipal de } \\
\text { Ibagué }\end{array}$ & $\begin{array}{l}\text { El } 17 \text { de enero de } \\
2008 \text { se ordenó } \\
\text { expedir medi- } \\
\text { camento dentro } \\
\text { de las } 48 \text { horas } \\
\text { siguientes. }\end{array}$ & $\begin{array}{l}\text { - Pasados cuatro meses sin que se } \\
\text { cumpliera la orden del fallo de tu- } \\
\text { tela, se presentó } \\
\text { incidente de desacato el } 22 \text { de } \\
\text { mayo de } 2008 . \\
\text { - Se sancionó por desacato el } 8 \text { de } \\
\text { abril de } 2008 . \\
\text { - Al dejar de suministrarle el medi- } \\
\text { camento, se solicitó el } 4 \text { de agosto } \\
\text { de } 2008 \text { abrir segundo incidente de } \\
\text { desacato. } \\
\text { - El } 11 \text { de noviembre de } 2008 \text { se } \\
\text { sancionó por desacato a la entidad. } \\
\text { - En marzo de } 2009 \text { no se le sumi- } \\
\text { nistró medicamento, por tanto se } \\
\text { solicitó en abril sancionar por des- } \\
\text { acato a la demandada. } \\
\text { - En mayo de } 2009 \text { se sancionó por } \\
\text { desacato a la entidad. } \\
\text { - El } 7 \text { de febrero de } 2010 \text { se solicitó } \\
\text { de nuevo incidente de desacato } \\
\text { porque se dejó de cumplir con la } \\
\text { orden. } \\
\text { - El } 26 \text { de marzo de } 2010 \text { la entidad } \\
\text { fue sancionada por desacato por } \\
\text { cuarta vez. } \\
\text { desacato a la entidad. } \\
\text { - En mayo y julio de } 2011 \text { no se le } \\
\text { suministró el medicamento, por } \\
\text { tanto se solicitó apertura de inci- } \\
\text { dente de desacato. }\end{array}$ \\
\hline
\end{tabular}




\begin{tabular}{|c|c|c|c|c|c|}
\hline $\begin{array}{l}\text { Wendy Yo- } \\
\text { lany Mateus } \\
\text { Chacón }\end{array}$ & $\begin{array}{l}\text { Capital Salud } \\
\text { EPS. Secretaría } \\
\text { de Salud }\end{array}$ & $\begin{array}{l}\text { Salud, } \\
\text { seguridad } \\
\text { social, } \\
\text { igualdad y } \\
\text { dignidad } \\
\text { humana }\end{array}$ & $\begin{array}{l}\text { Juzgado } \\
13 \text { Penal } \\
\text { Municipal } \\
\text { de Conoci- } \\
\text { miento de } \\
\text { Bogotá }\end{array}$ & $\begin{array}{l}\text { El } 18 \text { de diciem- } \\
\text { bre de } 2011 \text { se } \\
\text { ordenó expedir } \\
\text { las autorizaciones } \\
\text { para medicamen- } \\
\text { tos dentro de las } \\
48 \text { horas siguien- } \\
\text { tes. }\end{array}$ & $\begin{array}{l}\text {-No se cumplió con la orden, por } \\
\text { tanto, en febrero de } 2012 \text { se pre- } \\
\text { sentó incidente de desacato. } \\
\text { - En noviembre de } 2012 \text { el juez no } \\
\text { ha decidido sobre el desacato; ha } \\
\text { enviado cinco requerimientos a la } \\
\text { entidad para que cumpla. }\end{array}$ \\
\hline $\begin{array}{l}\text { Esteban } \\
\text { Rodríguez. } \\
\text { Agenciado } \\
\text { por Leonor } \\
\text { Beltrán de } \\
\text { Rodríguez }\end{array}$ & $\begin{array}{l}\text { Secretaría } \\
\text { Distrital de } \\
\text { Salud }\end{array}$ & Salud & $\begin{array}{l}\text { Juzgado } 50 \\
\text { Penal Mu- } \\
\text { nicipal de } \\
\text { Bogotá con } \\
\text { Función de } \\
\text { Garantías }\end{array}$ & $\begin{array}{l}\text { El } 14 \text { de junio de } \\
2012 \text { se ordenó } \\
\text { que de manera } \\
\text { inmediata se le } \\
\text { suministre medi- } \\
\text { camento y forma, } \\
\text { dosis y periodici- } \\
\text { dad indicada }\end{array}$ & $\begin{array}{l}\text {-Al no cumplirse con la orden del } \\
\text { fallo se solicitó incidente de des- } \\
\text { acato el } 27 \text { de julio de } 2012 \text {. } \\
\text { - Siendo noviembre de } 2012 \text {, solo } \\
\text { se han mandado tres requerimien- } \\
\text { tos y no ha habido respuesta ni } \\
\text { cumplimiento de la entidad. }\end{array}$ \\
\hline $\begin{array}{l}\text { Ana Silvia } \\
\text { Rondón Alca- } \\
\text { lá. Agenciada } \\
\text { por César } \\
\text { Alberto Maya } \\
\text { Rondón }\end{array}$ & $\begin{array}{l}\text { CAPRECOM } \\
\text { EPS }\end{array}$ & $\begin{array}{l}\text { Salud, vida } \\
\text { digna y } \\
\text { seguridad } \\
\text { social }\end{array}$ & $\begin{array}{l}\text { Juzgado } \\
8 \text { Civil del } \\
\text { Circuito de } \\
\text { Cartagena } \\
\text { de Indias }\end{array}$ & $\begin{array}{l}\text { El } 20 \text { de agosto de } \\
2011 \text { se ordenó a } \\
\text { la entidad sumi- } \\
\text { nistrar oxígeno }\end{array}$ & $\begin{array}{l}\text {-El } 30 \text { de agosto de } 2011 \text { se solicitó } \\
\text { sancionar por desacato a la enti- } \\
\text { dad. } \\
\text { - El juzgado envió cuatro requeri- } \\
\text { mientos, y solo hasta el } 9 \text { de mayo } \\
\text { de } 2012 \text { se abrió incidente de des- } \\
\text { acato por no cumplimiento de la } \\
\text { orden. }\end{array}$ \\
\hline $\begin{array}{l}\text { Wilmar Fer- } \\
\text { nando Velaz- } \\
\text { co Rincón }\end{array}$ & $\begin{array}{l}\text { Secretaría } \\
\text { Distrital de } \\
\text { Salud }\end{array}$ & $\begin{array}{l}\text { Salud, vida } \\
\text { y dignidad } \\
\text { humana }\end{array}$ & $\begin{array}{l}\text { Juzgado } \\
15 \text { Penal } \\
\text { Municipal } \\
\text { de Conoci- } \\
\text { miento de } \\
\text { Bogotá }\end{array}$ & $\begin{array}{l}\text { El } 20 \text { octubre de } \\
2010 \text { se ordenó } \\
\text { que en el térmi- } \\
\text { no de } 24 \text { horas } \\
\text { se proceda a } \\
\text { suministrar medi- } \\
\text { camento y trata- } \\
\text { miento integral }\end{array}$ & $\begin{array}{l}\text { - Al no cumplirse con la orden, en } \\
\text { noviembre de } 2010 \text { se solicitó san- } \\
\text { cionar por desacato a la entidad. } \\
\text { - Se mandaron seis requerimientos, } \\
\text { pero solo hasta el } 5 \text { octubre de } \\
2011 \text { se sancionó por desacato a la } \\
\text { entidad. }\end{array}$ \\
\hline $\begin{array}{l}\text { Edwin Darío } \\
\text { Velazco Rin- } \\
\text { cón. Agencia- } \\
\text { do por Flo- } \\
\text { relba Rincón } \\
\text { Velazco }\end{array}$ & $\begin{array}{l}\text { ARS Mutual } \\
\text { Ser }\end{array}$ & $\begin{array}{l}\text { Salud y } \\
\text { conexión } \\
\text { a la vida, } \\
\text { igualdad y } \\
\text { dignidad } \\
\text { humana }\end{array}$ & $\begin{array}{l}\text { Juzgado } 29 \\
\text { Penal Mu- } \\
\text { nicipal de } \\
\text { Bogotá }\end{array}$ & $\begin{array}{l}\text { Octubre } 11 \text { de } \\
2010 \text { se ordenó } \\
\text { que dentro de las } \\
48 \text { horas siguien- } \\
\text { tes se dieran los } \\
\text { demás medica- } \\
\text { mentos }\end{array}$ & $\begin{array}{l}\text {-Solo hasta el } 23 \text { de octubre de } \\
2011 \text { se sancionó por desacato a la } \\
\text { entidad y se multó con dos salarios } \\
\text { mínimos. }\end{array}$ \\
\hline
\end{tabular}




\begin{tabular}{|c|c|c|c|c|c|}
\hline $\begin{array}{l}\text { Flor Elba rin- } \\
\text { cón Velazco }\end{array}$ & $\begin{array}{l}\text { Humana Vivir } \\
\text { EPS }\end{array}$ & Salud & $\begin{array}{l}\text { Juzgado } \\
63 \text { Penal } \\
\text { Municipal } \\
\text { de Conoci- } \\
\text { miento de } \\
\text { Bogotá }\end{array}$ & $\begin{array}{l}\text { El } 14 \text { de julio de } \\
2009 \text { se solicitó } \\
\text { que en el término } \\
\text { de } 2 \text { días suminis- } \\
\text { tre medicamento } \\
\text { y tratamiento } \\
\text { integral }\end{array}$ & $\begin{array}{l}\text { El } 9 \text { noviembre de } 2010 \text { se sancio- } \\
\text { nó por desacato a la entidad y se } \\
\text { impuso una sanción con arresto } \\
\text { de } 6 \text { días y multa de } 10 \text { salarios } \\
\text { mínimos por no cumplir el fallo de } \\
2009 .\end{array}$ \\
\hline $\begin{array}{l}\text { Gustavo Rin- } \\
\text { cón Velazco }\end{array}$ & $\begin{array}{l}\text { Secretaría } \\
\text { Distrital de } \\
\text { Salud }\end{array}$ & $\begin{array}{l}\text { Salud y } \\
\text { vida digna }\end{array}$ & $\begin{array}{l}\text { Juzgado } \\
2 \text { Penal } \\
\text { Municipal } \\
\text { de Conoci- } \\
\text { miento de } \\
\text { Bogotá }\end{array}$ & $\begin{array}{l}\text { El } 27 \text { de septiem- } \\
\text { bre de } 2011 \text { se } \\
\text { ordenó que auto- } \\
\text { rizara exámenes y } \\
\text { suministre medi- } \\
\text { camento, copagos } \\
\text { y cuotas modera- } \\
\text { doras. }\end{array}$ & $\begin{array}{l}\text {-Solo se suministraron dos dosis, } \\
\text { por tanto se solicitó sancionar por } \\
\text { desacato a la entidad. } \\
\text { - El } 24 \text { de febrero de } 2012 \text { se san- } \\
\text { cionó por desacato y se ordenó } \\
\text { arresto de } 3 \text { días y multa de } 3 \text { sala- } \\
\text { rios mínimos. }\end{array}$ \\
\hline $\begin{array}{l}\text { Mary Vane- } \\
\text { gas Arellano }\end{array}$ & $\begin{array}{l}\text { Departamento } \\
\text { para la Pros- } \\
\text { peridad Social }\end{array}$ & $\begin{array}{l}\text { Debido } \\
\text { proceso }\end{array}$ & $\begin{array}{l}\text { Juzgado } 3 \\
\text { Adminis- } \\
\text { trativo del } \\
\text { Circuito de } \\
\text { Bogotá }\end{array}$ & $\begin{array}{l}\text { El } 13 \text { de mayo de } \\
2011 \text { se ordenó } \\
\text { que en un térmi- } \\
\text { no de } 5 \text { días se } \\
\text { realizara una eva- } \\
\text { luación de solici- } \\
\text { tud de reparación } \\
\text { administrativa }\end{array}$ & $\begin{array}{l}\text { - Al no haber cumplimiento, la } \\
\text { accionante solicitó en el segundo } \\
\text { semestre de 2011, que se sancio- } \\
\text { nara por desacato a la entidad. } \\
\text { - Al no haber una decisión favora- } \\
\text { ble o desfavorable se enviaron tres } \\
\text { memoriales para que se sancionara } \\
\text { por desacato. } \\
\text { - El } 17 \text { de abril de } 2012 \text { se declaró } \\
\text { que no había desacato por parte de } \\
\text { la accionada, sin embargo afirmó } \\
\text { que han transcurrido ocho meses } \\
\text { sin que haya cumplimiento de lo } \\
\text { dispuesto. } \\
\text { - Después se enviaron requerimien- } \\
\text { tos a la entidad en tres ocasiones: } \\
11 \text { mayo de } 2012,17 \text { mayo de } \\
2011,7 \text { junio de } 2011 . \text { Nunca hubo } \\
\text { cumplimiento. } \\
\text { - Se interpuso tutela contra inci- } \\
\text { dente de desacato por incurrir en } \\
\text { vía de hecho por defecto o fáctico. } \\
\text { Se concedió la tutela el } 8 \text { de agosto } \\
\text { de } 2012 .\end{array}$ \\
\hline
\end{tabular}




\begin{tabular}{|c|c|c|c|c|c|}
\hline $\begin{array}{l}\text { Roberto Ma- } \\
\text { cías Díaz }\end{array}$ & $\begin{array}{l}\text { Departamento } \\
\text { para la Pros- } \\
\text { peridad Social }\end{array}$ & Petición & $\begin{array}{l}\text { Juzgado } 22 \\
\text { Penal del } \\
\text { Circuito } \\
\text { de Conoci- } \\
\text { miento de } \\
\text { Bogotá }\end{array}$ & $\begin{array}{l}\text { El } 30 \text { de mayo de } \\
2012 \text { se ordenó } \\
\text { proceder, dentro } \\
\text { de las } 48 \text { horas } \\
\text { siguientes a la no- } \\
\text { tificación, a resol- } \\
\text { ver la petición }\end{array}$ & $\begin{array}{l}\text { - Pasado un mes no había cumpli- } \\
\text { miento, por tanto el } 25 \text { de junio del } \\
\text { presente año se procedió a solicitar } \\
\text { apertura de incidente de desacato. } \\
\text { - El } 3 \text { de junio de } 2012 \text { se envió re- } \\
\text { querimiento para que se cumpliera } \\
\text { con la orden. } \\
\text { - A noviembre de } 2012 \text {, aún no } \\
\text { ha habido respuesta por parte del } \\
\text { juzgado sobre el incidente. }\end{array}$ \\
\hline $\begin{array}{l}\text { Elver Gonzá- } \\
\text { lez Gutiérrez. } \\
\text { Agenciado } \\
\text { por Clara Ro- } \\
\text { cío Wilches }\end{array}$ & $\begin{array}{l}\text { Unidad para } \\
\text { la Atención } \\
\text { y Reparación } \\
\text { Integral a las } \\
\text { Víctimas }\end{array}$ & Petición & $\begin{array}{l}\text { Juzgado } \\
12 \text { Civil del } \\
\text { Circuito de } \\
\text { Bogotá }\end{array}$ & $\begin{array}{l}\text { El } 28 \text { de septiem- } \\
\text { bre de } 2012 \text { se } \\
\text { ordenó que en } \\
\text { el término de } 15 \\
\text { días se revise nue- } \\
\text { vamente la solici- } \\
\text { tud de reparación } \\
\text { individual por vía } \\
\text { administrativa }\end{array}$ & $\begin{array}{l}\text {-Se presentó solicitud de incidente } \\
\text { de desacato el } 24 \text { de octubre y aún } \\
\text { no ha habido respuesta. }\end{array}$ \\
\hline $\begin{array}{l}\text { Ramiro Ro- } \\
\text { mero Torres }\end{array}$ & $\begin{array}{l}\text { Departamento } \\
\text { para la Pros- } \\
\text { peridad Social }\end{array}$ & Petición & $\begin{array}{l}\text { Juzgado } \\
38 \text { Civil del } \\
\text { Circuito de } \\
\text { Bogotá }\end{array}$ & $\begin{array}{l}\text { El16 de abril de } \\
2012 \text { se ordenó } \\
\text { que en el término } \\
\text { de } 48 \text { horas se } \\
\text { resolviera la soli- } \\
\text { citud radicada el } 6 \\
\text { de septiembre de } \\
2011\end{array}$ & $\begin{array}{l}\text {-El } 24 \text { de junio de } 2012 \text { se presentó } \\
\text { incidente de desacato y el juzgado } \\
\text { aún no ha fallado, pues la entidad } \\
\text { accionada no responde desde el } 15 \\
\text { de agosto de } 2012 \text {. }\end{array}$ \\
\hline $\begin{array}{l}\text { Mya Sophia } \\
\text { Campos } \\
\text { Ramos. } \\
\text { Agenciada } \\
\text { por Angélica } \\
\text { Rocío Ramos } \\
\text { Acero }\end{array}$ & $\begin{array}{l}\text { SALUDCOOP } \\
\text { E.P.S. }\end{array}$ & $\begin{array}{l}\text { Salud, } \\
\text { seguridad } \\
\text { social y } \\
\text { vida digna }\end{array}$ & $\begin{array}{l}\text { Juzgado } 73 \\
\text { Civil Mu- } \\
\text { nicipal de } \\
\text { Bogotá }\end{array}$ & $\begin{array}{l}\text { El } 24 \text { de septiem- } \\
\text { bre se ordenó que } \\
\text { en el término de } \\
48 \text { horas se auto- } \\
\text { rice sesiones de } \\
\text { equinoterapia }\end{array}$ & $\begin{array}{l}\text { - Siendo noviembre de } 2012 \text {, solo } \\
\text { se ha mandado un requerimiento } \\
\text { a la entidad para que responda, lo } \\
\text { cual no ha generado ningún efecto, } \\
\text { ni se ha cumplido. } \\
\text { - No ha habido respuesta ni cumpli- } \\
\text { miento de la entidad. }\end{array}$ \\
\hline
\end{tabular}

\section{PROBLEMÁTICA EN EL TRÁMITE INCIDENTAL DE DESACATO PARA HACER EFECTIVA LA ACCIÓN DE TUTELA}

Con fundamento en el estudio sobre la naturaleza de la acción de tutela, fin esencial, regulación frente a los mecanismos de cumplimiento, específicamente el trámite incidental de desacato, y observando el actuar de los jueces constitucio- nales al enfrentarse a este, resulta pertinente analizar varios aspectos para resolver la hipótesis planteada: la eficacia del trámite incidental de desacato como instrumento para que se cumpla con lo dispuesto en la orden del fallo de tutela. 


\section{A. Problemática en la falta de regulación concreta del trámite incidental de desacato}

En primera instancia cabe resaltar de lo expuesto, que el Constituyente de 1991 buscaba que en el ordenamiento jurídico colombiano existiese un mecanismo informal, eficaz y rápido para la protección urgente de los derechos fundamentales de las personas, cuando estos estuviesen siendo vulnerados o amenazados. Así, su fin esencial era encontrar una manera por la cual las personas pudiesen acudir ante cualquier juez de la República para que se les protegieran los derechos inherentes a su ser, sin dilación alguna.

En virtud de lo anterior, y con el fin de hacer de la regulación de la acción de tutela un mecanismo más claro y reglamentado para los jueces, se promulgó el Decreto 2591 de 1991, dentro del cual se codificaron las vías de cumplimiento con las que cuenta el juez constitucional y el accionante para hacer cumplir la orden del fallo de tutela. Resultaba, a grandes rasgos, una norma detallada en la cual el juez tendría un marco jurídico para actuar frente al incumplimiento de la orden proferida en la sentencia.

Sin embargo, como había de esperarse, el decreto no remedió completamente esta problemática, al contrario, ante los vacíos en su regulación se promulgó el Decreto 306 de 1992, en el cual se determinaron los principios aplicables para interpretar el procedimiento previsto por el Decreto 2591 de 1991. Así las cosas, como se expuso anteriormente, para la interpretación de las disposiciones sobre el trámite de la acción de tutela, incluido el trámite incidental de desacato, se estipuló que se aplicarían los principios generales del Código de Procedimiento Civil.

¿Qué sucedió entonces? Esta apresurada o bien intencionada disposición no tuvo en cuenta que al establecer para el trámite de la acción de tutela principios basados en el Código de Procedimiento Civil desnaturalizaba en la práctica el fin primordial de esta institución. Como se pudo evidenciar en el estudio de los casos concretos, el juez, al encontrarse con esta disposición, se remite al trámite incidental regulado en el procedimiento civil, extendiendo así los plazos sin tener en cuenta que lo que se está desacatando es la protección a un derecho fundamental. Lamentablemente, los jueces y el accionado olvidan lo que buscaba el Constituyente del 1991 con esta acción: la protección urgente e inmediata de los derechos fundamentales de las personas.

Al remitirse a procedimientos ordinarios, el trámite de cumplimiento de la orden de acción de tutela se convierte en un recurso ordinario, sin preferencia alguna. Por tanto, el término perentorio para cumplir la orden de tutela y la orden del fallo de tutela pasan a ser un "canto a la bandera”. ¿Qué sentido tiene que el juez disponga de un tiempo urgente de diez días para fallar en primera instancia y veinte días en segunda instancia, si la orden de la sentencia de tutela se cumple meses o incluso años después?

Por lo expuesto, queda claro que la protección constitucional de los derechos fundamentales pierde todo su sentido cuando la persona afectada debe acudir a un mecanismo sancionatorio sin términos y su protección se da en el plazo 
que la parte accionada decide tomarse para cumplir. No quiere decirse que los jueces no cumplan con su trabajo, pero queda en el ambiente la sensación que estos, ante la falta de regulación, proceden a actuar a su discrecionalidad, sin considerar la naturaleza de la acción de tutela y, por tanto, el carácter inmediato que tiene su orden.

Estos derechos constitucionales fundamentales se tornan así en una expectativa para quienes ya tienen un fallo de protección, pues el término perentorio que fija el juez constitucional al faIlar la tutela se extiende a tal punto, que pierde sentido estructurar la decisión, tal y como se ha venido desarrollando. ¿De qué sirve dar una orden y un tiempo perentorio de cumplimiento si no hay términos estrictos para que un juez decida sobre un trámite incidental de desacato? o lo que es peor, ¿de qué sirve tener una sentencia de tutela fallada en diez días si lo que esta ordena se cumplirá en lapsos de tiempo muchísimo mayores a los que corresponderían a un mecanismo preferente constitucional?

En este orden de ideas, encontramos entonces que al no existir términos, el juez procede a actuar según su sana experiencia asimilando los casos con procesos civiles, olvidando que este mecanismo se instituyó, en parte, para evitar la ocurrencia de un perjuicio irremediable.

\section{B. La falta de recursos para alegar la decisión del incidente de desacato}

Dentro de la regulación del incidente de desacato se estipuló que, de ser desfavorable para el accionante la decisión sobre el desacato, no pro- cede recurso alguno, pues solo procede el grado de consulta y no el de apelación cuando la decisión es adversa a la parte interesada. Aunque esta problemática ya fue objeto de demanda de inconstitucionalidad, la Corte Constitucional al realizar el estudio contra el artículo 52 del Decreto 2591 de 1991, en sentencia C-243 de 1996 determinó que la norma era exequible. Al respecto, la presente crítica tomará algunos puntos discutidos por la Corte Constitucional de la época al declarar exequible la norma, con miras a encontrar posibles vicios estructurales en la regulación del artículo 52 del decreto mencionado.

Las disposiciones que se toman corresponden a la sentencia de constitucionalidad de 1996. En primera instancia, la Corte expresó que:

la correcta interpretación y alcance del artículo 52 del Decreto 2591 de 1991, parcialmente demandado de inexequibilidad, no puede ser otro que el que se deduce de su tenor literal y del sentido natural y obvio de sus palabras: es decir, consagra un trámite incidental especial, que concluye con un auto que nunca es susceptible del recurso de apelación, pero que si dicho auto es sancionatorio, debe ser objeto del grado de jurisdicción llamado consulta, cuyo objeto consiste en que el superior jerárquico revise si está correctamente impuesta la sanción, pero que en sí mismo no se erige como un medio de impugnación. Y ello es así por cuanto el trámite de la acción de tutela es un trámite especial, preferente y sumario que busca la protección inmediata de los derechos fundamentales, lo cual implica una especial relevancia del principio de celeridad.

Conforme a lo expuesto, podría decirse entonces que el legislador, en atención a la relevancia 
del principio de celeridad del trámite de acción de tutela, determinó que no habría ningún recurso que hiciese más largo el cumplimiento de la orden del fallo de tutela. Esto pudo sonar así en los primeros años, cuando la acción de tutela se mostró como algo completamente acorde con su fin esencial, pero si se observa en la práctica, el trámite incidental de desacato refleja, precisamente, que los principios de celeridad de la acción de tutela y su intención cayeron en el vacío.

Como se aprecia en los casos concretos expuestos, hay ocasiones en que la parte accionante debe acudir en varias oportunidades ante el juez para que sancione por desacato al sujeto que está incumpliendo, porque este al fallar el primer desacato no le dio el alcance necesario para la protección del derecho y, en otros, llega hasta a exponer que no se evidencia una responsabilidad subjetiva frente al incumplimiento del fallo pero advierte a la entidad que de no cumplir en un término perentorio de dos días será sancionada por desacato. ¿Qué cambiarían dos días de plazo en cuanto a determinar una responsabilidad objetiva o subjetiva del actor? Teniendo en cuenta la responsabilidad subjetiva necesaria para poder sancionar por desacato, se ha dicho que debe estar probada la negligencia o desinterés de la parte accionada. ¿Cambia esta condición entonces en dos días?

Los casos concretos parecieran más bien mostrar que el juez da largas a un procedimiento urgente produciendo requerimientos y memoriales para no proceder a sancionar al sujeto que incumple. Cuál es el fin de la acción de tutela ¿proteger a quienes son vulnerables frente a una situación o evitar sanciones para el que incumpla?

Conforme a lo dicho, y observando que el trámite incidental de desacato se ha convertido en un mecanismo ineficaz para exigir el cumplimiento inmediato de la orden de tutela, y que su acatamiento puede tardar en algunas ocasiones meses o años en resolverse, no resultaría más negativo que las partes, tanto el accionante como el accionado, tuvieran la posibilidad de apelar una decisión. A lo mejor, al abrirse la posibilidad de un recurso contra las decisiones, se haría más estricto el tiempo en el cual fallen los jueces y su fundamento, pues el grado de consulta solo observa la legalidad de la decisión de desacato.

\section{El incidente de desacato no llega a revisión a la Corte Constitucional}

Como ya se explicó, el artículo 241 de la Carta Política no establece dentro de las funciones de la Corte Constitucional la de revisar los incidentes de desacato, únicamente contempla la eventual revisión de las decisiones judiciales proferidas dentro de la acción de tutela. Aunque se entiende que la facultad de revisión surge para sentar una jurisprudencia constitucional con el fin de aclarar el alcance de un derecho, la posible revisión del incidente de desacato podría traer, al igual que en la sentencia de tutela, una seguridad jurídica para la parte accionante.

La seguridad jurídica es un valor implícito dentro de nuestro ordenamiento, proyectado en todos los ámbitos de las relaciones entre los 
individuos. La Corte Constitucional interpretó en sentencia SU-047 de 1999 este principio indicando:

Todo tribunal, y en especial el juez constitucional, debe ser consistente con sus decisiones previas... Por elementales consideraciones de seguridad jurídica y de coherencia del sistema jurídico, pues las normas si se quiere que gobiernen la conducta de los seres humanos deben tener un significado estable, por lo cual las decisiones de los jueces deben ser razonablemente previsibles (...) esta seguridad jurídica es básica para proteger la libertad ciudadana y permitir el desarrollo económico, ya que una caprichosa variación de los criterios de interpretación pone en riesgo la libertad individual, así como la estabilidad de los contratos y de las transacciones económicas, pues las personas quedan sometidas a los cambiantes criterios de los jueces, con lo cual difícilmente pueden programar autónomamente sus actividades.

Conforme a lo dicho, podría establecerse entonces que al poder ser revisado el incidente de desacato, el juez constitucional encargado de decidir el fallo se vería inmerso dentro de unos principios constitucionales establecidos, que harían que sus actuaciones fueran más homogéneas, rápidas y conformes con lo establecido en la Carta Política de 1991.

\section{CONCLUSIONES}

Habiendo hecho un estudio sucinto de la institución jurídica de la acción de tutela y el incidente de desacato, y de haber expuesto cómo este está regulado, su aplicación en la práctica y sus posibles falencias, resulta necesario analizar si efectivamente el trámite incidental de desacato es un mecanismo eficaz para lograr el cumplimiento de la orden de tutela.

Con el fin de responder lo anterior, es necesario precisar el concepto de eficacia. Aunque este término ha tenido varias definiciones en materia doctrinal, en este texto se empleará la establecida por García Villegas en su libro La eficacia simbólica del derecho. Así pues, la eficacia aquí se entenderá como "aquella causalidad entre el propósito buscado por la norma y su resultado efectivo". Por lo tanto, una norma se puede considerar eficaz cuando es obedecida de manera general, y en caso de incumplimiento, es aplicada la correspondiente sanción por parte de los jueces, mostrando así una correspondencia entre las acciones y lo dispuesto por las normas (Vilajosona, 2010, p. 185).

Según lo establecido por García Villegas en la obra citada, resulta importante el estudio de la eficacia de una institución jurídica, pues se ha encontrado que no siempre el objetivo perseguido por la norma puede ser percibido a través de su lectura, del análisis de su proceso de creación o no ser efectivo en la práctica, pues "la existencia de una norma no se explica simplemente por su validez formal sino por su capacidad para producir un cierto comportamiento en los individuos receptores de la norma" (García, 1993, p. 93).

De acuerdo con lo anterior, se puede afirmar entonces que aunque el constituyente de 1991 buscaba la creación de un mecanismo eficaz y rápido para lograr la protección de los derechos constitucionales fundamentales de las 
personas que se encontraran en situación de debilidad en razón de la amenaza o vulneración de sus derechos, las vías de cumplimiento resultan ser completamente ineficaces para el fin buscado. Como se pudo observar en la exposición de los casos concretos, aunque el artículo 52 del Decreto 2591 de 1991 buscaba crear un recurso de carácter sancionatorio y correccional para el cumplimiento de la orden del fallo de tutela, en la práctica este ha sido inútil para tal propósito.

Si bien el juez constitucional al decidir sobre la acción de tutela actúa conforme al fin propuesto por el constituyente de 1991 y falla sin ningún tipo de dilación o demora, el agraviado encuentra que el mecanismo estatuido para hacer cumplir lo dispuesto en la orden del fallo de tutela es lento e ineficaz para el fin propuesto, desfigurándose así la naturaleza misma de la acción de tutela.

La falta de términos específicos en el trámite incidental de desacato, su falencia respecto a un medio detallado que establezca el actuar del juez, la imposibilidad de acudir a un recurso en caso de que el juez considere que no existe responsabilidad subjetiva en el incumplimiento, y la falta de reglas claras por parte de la Corte Constitucional respecto al incidente de desacato, afectan de manera determinante la eficacia del trámite incidental de desacato para el cumplimiento de la orden del fallo de tutela. Respecto a lo anterior, cabe recordar que "mientras más generales sean los términos de una norma, más lugar habrá para el ejercicio de una interpretación amplia y por tanto más difícil será el establecimiento de criterios de eficacia" (García, 1993, p. 97).
En este orden de ideas, puede concluirse que el trámite incidental de desacato resulta ser un mecanismo ineficaz para lograr el cumplimiento de la orden del fallo de tutela, lo cual hace que surja una pregunta más ¿puede ser la falla del trámite incidental de desacato un síntoma de la desnaturalización de la acción de tutela?

\section{Bibliografía}

\section{Doctrina}

Asamblea Nacional Constituyente de 1991. Informe ponencia para primer debate en Plenaria. Gaceta Constitucional $n^{\circ} .70$.

Barreto, José Vicente. Acción de tutela. Teoría y práctica. Legis, Bogotá, 1997.

BitAR A., Andrés Felipe. La tutela sin dientes: deficiencias reglamentarias del desacato. Universidad de los Andes, Bogotá, 2010.

Bonilla, Daniel. Hacia un nuevo derecho constitucional. Universidad de los Andes, Bogotá, 2005.

Brewer-Callas, A. Constitutional protection of human rights in Latin America: a comparative study of amparo proceedings. Cambridge Press, New York, 2009.

Castro, Jaime. Constitución Política de Colombia. Concordancias, referencias históricas e índice analítico. Universidad del Rosario, Bogotá, 2008.

Consejo Superior de la Judicatura y Deutche Gesellschaft fur Techinische Zusammenarbeit. Ac- 
ción de tutela, una reforma necesaria. Bogotá, 2003.

Correa H., Néstor Raúl. Derecho procesal de la acción de tutela. Tercera Edición. Editorial Ibáñez, Bogotá, 2009.

Dueñas R., Óscar José. Acción y procedimiento en la tutela. Cuarta Edición. Ediciones Librería Profesional, Bogotá, 2001.

Esguerra Portocarrero, Juan Carlos. Proyecto de acto reformatorio de la Constitución Política. Gaceta Constitucional, n. 24, marzo 20 de 1991.

García Villegas, Mauricio. La eficacia simbólica del derecho: examen de situaciones colombianas. Primera edición. Ediciones Uniandes, Bogotá.

Ministerio de Justicia y del Derecho y Centro de InvestIGACIONES SOCIOJURÍDICAS -CIJUS-. Incidencia social de la acción de tutela. Bogotá, 1996.

Olano G., Hernán Alejandro. Constitución Política de Colombia. Octava Edición. Ediciones Doctrina y Ley Ltda., Bogotá, 2011.

Paullas P., Enrique. El recurso de protección ante el derecho comparado. Editorial Jurídica de Chile, Santiago de Chile, 1990.

Presidencia de la República. Los derechos fundamentales, protección de todos: el libro blanco de la tutela. Bogotá, Imprenta Nacional de CoIombia.

Quinche R., Manuel Fernando. Derecho constitucional colombiano. De la Carta de 1991 y sus reformas. Cuarta Edición. Ediciones Doctrina y Ley Ltda., 2010.

Rosales A., Rómulo. Formulario del juicio de amparo. Editorial Porrúa, México, 1990. En: Seminario sobre la Tutela y el Derecho de Amparo. "El derecho de tutela, vigencia y futuro". Editorial Ibáñez, Bogotá, 2003.

Tово R., Javier. Corte Constitucional y el control de constitucionalidad en Colombia. Cuarta Edición. Editorial Ibáñez, Bogotá, 2011.

Vidal Perdomo, Jaime y Sáchica, Luis Carlos. La Constituyente de 1991: compilación, comentarios y análisis jurídico de sus antecedentes. Cámara de Comercio de Bogotá, Bogotá, 1991.

Vilajosana M., Josep. El derecho en acción: la dimensión de las normas jurídicas. Marcial Pons, Madrid, 2010.

\section{Entrevista}

Dr. Santiago Aristizábal, abogado de ACOPEL (Asociación Colombiana de Pacientes con Enfermedades de Depósito Lisosomal).

\section{Jurisprudencia}

Corte Constitucional. Sentencia T-001 de 1992

Corte Constitucional. Sentencia T-116 de 1993

Corte Constitucional. Sentencia T-014 de 1994

Corte Constitucional. Sentencia T-034 de 1994

Corte Constitucional. Sentencia T-327 de 1994 
Corte Constitucional. Sentencia T-211 de 1995

Corte Constitucional. Sentencia C-243 de 1996

Corte Constitucional. Sentencia T-554 de 1996

Corte Constitucional. Sentencia T-081 de 1997

Corte Constitucional. Sentencia C-092 de 1997

Corte Constitucional. Sentencia T-335 de 1997

Corte Constitucional. Sentencia T-763 de 1998

Corte Constitucional. Sentencia T-961 de 1999

Corte Constitucional. Sentencia T-063 de 2000

Corte Constitucional. Sentencia C-728 de 2000

Corte Constitucional. Sentencia T-942 de 2000

Corte Constitucional. Sentencia T-635 de 2001

Corte Constitucional. Sentencia 136A de 2002

Corte Constitucional. Sentencia T-188 de 2002

Corte Constitucional. Sentencia T-553 de 2002

Corte Constitucional. Sentencia T-1110 de 2002

Corte Constitucional. Sentencia T-086 de 2003

Corte Constitucional. Sentencia T-264 de 2003

Corte Constitucional. Sentencia T-441 de 2003

Corte Constitucional. Sentencia T-459 de 2003

Corte Constitucional. Sentencia T-458 de 2003
Corte Constitucional. Auto 005 de 2004

Corte Constitucional. Auto 010 de 2004

Corte Constitucional. Auto 138 de 2004

Corte Constitucional. Auto 178 de 2005

Corte Constitucional. Sentencia T-053 de 2005

Corte Constitucional. Sentencia T-368 de 2005

Corte Constitucional. Sentencia T-1113 de 2005

Corte Constitucional. Sentencia T-086 de 2006

Corte Constitucional. Sentencia T-158 de 2006

Corte Constitucional. Sentencia T-171 de 2009

Corte Constitucional. Sentencia T-121 de 2010

Corte Constitucional. Sentencia T-123 de 2010

Corte Constitucional. Sentencia T-611 de 2011

Corte Constitucional. Sentencia T-1048 de 2010

Corte Constitucional. Sentencia C-203 de 2011

Corte Constitucional. Sentencia 139 de 2011

Corte Constitucional. Sentencia T-485 de 2011

Corte Constitucional. Sentencia T-512 de 2011

Corte Constitucional. Sentencia T-661 de 2011

Corte Constitucional. Sentencia T-010 de 2012

Corte Constitucional. Auto 106 de 2012 
Normatividad

Corte Constitucional. Sentencia T-390 de 2012 Constitución Política de Colombia de 1991

Decreto 2591 de 1991

Decreto 306 de 1992 